\title{
Monsoonally influenced circulation around coral reef islands and seasonal dynamics of reef island shorelines
}

\author{
P.S. Kench ${ }^{\text {a,* }}$, K.E. Parnell ${ }^{\text {b }}$, R.W. Brander ${ }^{c}$ \\ a School of Geography and Environmental Science, The University of Auckland, Private Bag 92019, Auckland, New Zealand \\ b School of Earth and Environmental Sciences, James Cook University, Townsville, QLD 4811, Australia \\ c School of Biological, Earth and Environmental Sciences, University of New South Wales, Sydney 2052, Australia
}

\section{A R T I C L E I N F O}

\section{Article history:}

Received 16 October 2008

Received in revised form 17 July 2009

Accepted 27 July 2009

Available online 6 August 2009

Communicated by J.T. Wells

\section{Keywords:}

reef islands

waves

currents

coral reefs

hydrodynamics

morphodynamics

\begin{abstract}
A B S T R A C T
Synchronous measurements of reef flat waves and nearshore currents were made around the perimeter of three coral reef islands in the central Maldives. Nearshore current velocities were shown to be tidally modulated in most instances with maximum velocities associated with lower tidal stages. Peak currents were consistently observed on the windward and lateral flanks of island shorelines $\left(0.3-0.4 \mathrm{~ms}^{-1}\right)$. The relatively low elevation of reef surfaces and medium to low energy incident wave energy ( $\mathrm{Hs} \sim 0.2-0.3 \mathrm{~m}$ ) accounts for low tidal stage peaks in velocity as this corresponds to the period when wave setup-induced current processes are maximised. Significantly, all nearshore currents were unidirectional and alongshore. The generation of unidirectional alongshore flow patterns results from island configuration which deflects flow and variations in reef geometry that control: spatial variations in wave-setup around the reef platform edge and at the island shoreline, which can drive alongshore currents; the presence of a nearshore moat that channelizes flow in the nearshore: and variations in reef geometry where topographic low points act as preferential drainage points. Results show that changes in monsoon conditions, that modulate wind and wave patterns from the west to northeast, can force substantial changes in reef platform and nearshore current flows, but that the degree of change is dependent on reef platform shape and position in the atoll. The circular study island was found to exhibit a near-complete reversal in unidirectional flow from northeast flow in the westerly monsoon to southwest flow in the northeast monsoon. However, the elongate and triangular shaped reef platforms exhibited more localised changes in flow patterns. Significantly, those shorelines that exhibit the greatest changes in shoreline currents correspond to the sections of coast that exhibit the largest morphological adjustments between seasons. Results provide significant insights for the morphodynamics of reef platform islands. In particular, the nearshore process regime is dominated by alongshore processes. Furthermore, reef platform shape and the magnitude of change in direction of wave approach to reef platforms provide critical indicators of the morphodynamic behaviour of reef platform islands.
\end{abstract}

(c) 2009 Elsevier B.V. All rights reserved.

\section{Introduction}

Coral reef islands are low lying accumulations of sediment deposited on coral reef platforms. The conditions for island accumulation require sediment supply, accommodation space and physical processes (driven primarily by waves and currents) that transport sediments to nodal locations on reefs (Stoddart and Steers, 1977) Incident energy and its refraction around the reef platform structure is an important boundary control stimulating geomorphic processes on reef tops (Gourlay, 1988). However, more important for island formation and change is the magnitude and behaviour of residual energy on the reef surface following wave breaking and energy dissipation

\footnotetext{
* Corresponding author. Tel.: +64 9373 7599x88440; fax: +64 93734797.

E-mail addresses: p.kench@auckland.ac.nz (P.S. Kench), kevin.parnell@jcu.edu.au (K.E. Parnell), rbrander@unsw.edu.au (R.W. Brander).
}

across the reef edge, which generates reef flat currents. This residual energy becomes the stimulus for sediment entrainment and transport on reef surfaces promoting the infill of lagoons (Macintyre, et al., 1987; Kench, 1998a; Purdy and Gischler, 2005), island accumulation (Woodroffe, et al., 1999; Yamano et al., 2000) and reef island beach change (Kench and Brander, 2006a).

Wave and current generated processes across coral reefs are known to be important for the ecological functioning of reef systems. Currents have been identified as critical for: the supply of nutrients, food, renewal of water and oxygen and their uptake by corals (Jokiel, 1978; Nakamori et al., 1992; Hearn et al., 2001); the removal of metabolic wastes and flushing of reef lagoons (Frith, 1982; Kench, 1998b; Kraines et al., 1998); and, the dispersal and recruitment of larvae (Hamner and Wolanski, 1988; Black, 1993; Abelson and Denny, 1997). Oceanographic studies of wave and current processes have largely focussed on: wave-reef edge interactions (Roberts, 1975; Lee 
and Black, 1978; Roberts and Suhayda, 1983; Roberts et al., 1992); controls on and the generation of wave setup at the reef edge (Tait, 1972; Gourlay, 1994; Symonds et al., 1995; Gourlay, 1996a,b; Hearn, 1999; Gourlay and Colleter, 2005); and broad scale circulation and flushing of reef and lagoon systems (Frith and Mason, 1986; Wolanski and King, 1990; Prager, 1991; Kench, 1998b; Kraines et al., 1998; Yamano et al., 1998). Collectively these studies have highlighted: the depth dependence of the reef in controlling wave breaking; the large wave energy attenuation rates resulting from wave breaking at the reef edge; the generation of wind and wave setup gradients driving across reef flows; and controls on lagoon flushing.

Despite the considerable advances in understanding reef oceanography, there are still a number of gaps in understanding reef flat wave and current generated processes particularly as they relate to geomorphic processes. First, as noted by Lugo-Fernández et al. (2004) understanding of currents on and around coral reefs lags behind knowledge of wave-reef interactions. They further highlight that an important reason for this gap is the lack of simultaneous measurements of currents on coral reefs (Gerritsen, 1981; Hardy et al., 1990; Hearn, 1999) although see Storlazzi et al. (2004) and Storlazzi et al. (2006) for examination of fringing reef currents and implications for sediment suspension. Second, few studies have attempted to undertake detailed measurements of reef flat waves and currents other than in 2-dimensional cross reef arrays. Such approaches are unable to account for along-reef processes. Third, there have been few studies of detailed changes in wave energy and current generation across reef flat surfaces. Fourth, few studies have attempted to document spatial and temporal variations in wave and current energy with a specific focus on their importance for the development and change to sedimentary deposits such as reef islands. Recently a number of studies have begun to examine such interactions, such as the potential role of wave energy in driving geomorphic processes in the nearshore of reef islands (Brander et al., 2004; Kench and Brander, 2006b; Kench et al., 2006; Samosorn and Woodroffe, 2008; Kench et al., 2009).

There are also few studies that have attempted to link observations of morphological change in reef islands to specific process mechanisms. Studies of the geomorphic behaviour of reef islands have focussed either on inter-annual or decadal-scale changes in island size and position on reefs (e.g. Taylor, 1924; Stoddart et al., 1978; Flood, 1984; Aston, 1995) or on the susceptibility of islands to change during catastrophic storms (e.g. Stoddart, 1963, 1971; Maragos et al., 1973; Flood and Jell, 1977; Bayliss-Smith, 1988; Harmelin-Vivien, 1994). Causal relationships between climate and island behaviour have been suggested in a number of studies (Umbgrove, 1947; Verstappen, 1954; Flood, 1986) where changes in prevailing wind direction and strength and its assumed influence on wave climate have been considered to control changes in island position and shape. With the exception of storm events (e.g. Maragos et al., 1973; Stoddart, et al., 1982) few studies have examined the influence of short-term and predictable shifts in climate on island shoreline behaviour.

Kench and Brander (2006a) undertook a detailed analysis of beach dynamics around reef platform islands in the Maldives. Their study identified substantial morphological change in beach position which appeared to be related to changes in seasonal monsoon conditions. Their observations suggested that the magnitude of beach change was controlled by the interplay between reef platform shape and incident wave conditions, which govern reef platform wave and current processes, as outlined by Gourlay (1988). However, the detailed process mechanism driving these morphological adjustments remains unclear.

This study examines the process mechanism driving reef shoreline morphodynamics in the Maldives. The specific aims are to: i) present simultaneous observations of incident wave and reef flat currents around three isolated reef platform islands; ii) determine the influence of the Indian monsoon on reef flat circulation patterns and iii) examine whether observed hydrodynamic processes can account for documented seasonal shoreline dynamics of reef islands.

\section{Field setting}

The Maldives is a $868 \mathrm{~km}$ long archipelago comprising a double chain of 22 atolls that extend from $6^{\circ} 57^{\prime} \mathrm{N}$ to $0^{\circ} 34^{\prime} \mathrm{S}$ in the central Indian Ocean (Fig. 1a). The focus of this study are three reef platforms in South Maalhosmadulu atoll (Fig. 1b) which is approximately $40 \mathrm{~km}$ long and wide and, unlike many Pacific atolls, has a discontinuous rim characterised by numerous passages up to $40 \mathrm{~m}$ deep and $4500 \mathrm{~m}$ wide. The lagoon reaches depths of $80 \mathrm{~m}$ and contains numerous patch reefs and faros (Fig. 1b). A total of 56 islands are located on peripheral and lagoonal reef platforms.

\subsection{Reef platforms}

Reef platforms from the west (Dhakandhoo) centre (Hulhudhoo) and northeast (Thiladhoo) sectors of the atoll were selected for this study (Fig. 1c-e). The reef platforms are relatively small and have differing dimensions and shapes (Fig. 1c-e). Each platform rises steeply from lagoon water depths of $60-80 \mathrm{~m}$ where there is a sharp transition at the reef crest to a near horizontal reef flat surface. The reef flat surfaces are generally characterised by a living outer reef flat containing live Porites, Acroporid and Millepora species. The outer reef flats are situated below the level of LAT (lowest astronomical tide) indicating there is still accommodation space for vertical reef growth. There is a transition from the living reef flat surface to lower elevation sand and rubble surface within $30-50 \mathrm{~m}$ of the island shorelines. This transition is marked by a sharp morphological break (vertical step ranging from 0.3 to $1.0 \mathrm{~m}$ ) from the living outer reef flat to the lower 'moat' surface (Fig. 1f, Table 1). These moats typically encircle each island, although where the reef width is large the moat boundary is more difficult to delineate.

\subsection{Reef islands}

The islands are small and of comparable area but occupy varying proportions of their reef flats (Fig. 1). Dhakandhoo Island is situated on the eastern portion of the reef, Hulhudhoo occupies the centre of its circular reef platform, whereas Thiladhoo is positioned toward the southern and eastern portion of its reef platform. The islands have a maximum elevation of approximately $2.2 \mathrm{~m}$ above mean sea level $(\mathrm{msl})$. The seasonal morphological behaviour of the beaches that fringe eight islands in South Maalhosmadulu atoll (including the three study islands) was documented by Kench and Brander (2006a) based on repeat global positioning system surveys. In summary, they found: i) large seasonal adjustments in beach position around island shorelines; ii) beach changes were correlated with different monsoon seasons; iii) both the magnitude and planform adjustments in beach position varied between islands of differing shape. These findings were summarised by the reef island oscillation index in which circular and elongate islands were shown to exhibit the most and least dynamic shoreline behaviour respectively.

\subsection{Climatic regime}

The climate of the Maldives can be divided into two monsoon periods with marked differences in wind direction that are confined to a narrow range of wind angles. Summary wind data since 1964 (Fig. 2a, b) indicate that the Maldives experience southwest to northwest winds $(\sim 225$ $315^{\circ}$ ) from April to November (westerly monsoon) with a mean wind speed of $5.0 \mathrm{~ms}^{-1}$. In contrast, winds from the northeast-east $(\sim 45-$ $90^{\circ}$ ) prevail from December to March (northeast monsoon) with a mean wind speed of $4.8 \mathrm{~ms}^{-1}$ (Fig. 2a, b). Wind strength is most variable during the cross-over between northeast and westerly monsoons with 


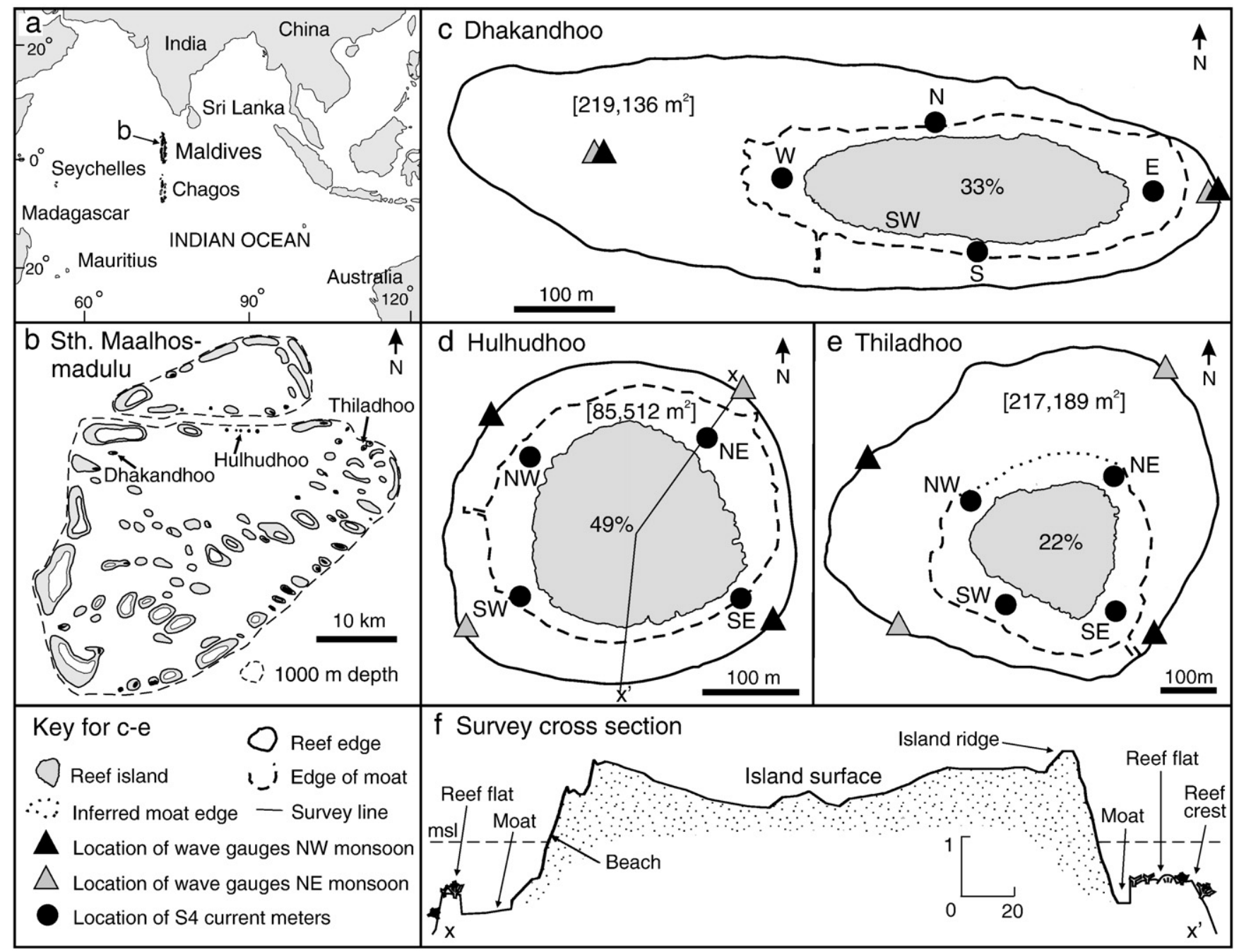

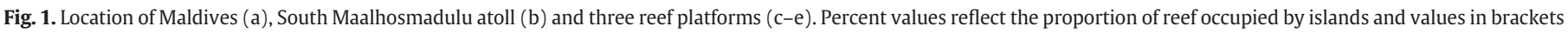
denotes the area of each reef platform. f) Topographic survey (NE-S) across Hulhudhoo reef platform and island showing typical reef and island morphology.

mean wind speed falling to $3.5 \mathrm{~ms}^{-1}$ in March (Department of Meteorology, 1995).

Information on the deepwater wave climate is limited, but satellite altimetry wave climate data (for a ten-year period) for the region (Young, 1999) indicates that the dominant swell approaches from southerly directions (Fig. 2c). On a seasonal basis, swell is from the south-southwest from April to November with a peak significant wave height $\left(H_{s}\right)$ of $1.8 \mathrm{~m}$ in June, and from the south to southeast directions from November to March with a minimum $H_{\mathrm{s}}$ of $0.75 \mathrm{~m}$ in March (Fig. 2c). The estimates and seasonality in wave height conditions are consistent with independent analysis of a shorter three-year record of satellite altimetry data by Harangozo (1992).

\subsection{Lagoon oceanography}

The broadscale oceanography of the atolls of the Maldives have been poorly studied. Atoll-specific circulation and current patterns are controlled by the interaction of tide and wave processes with atoll structure. As noted above the heavily dissected character of the South Maalhosmadulu atoll rim indicates the effective aperture of the atoll (proportion of gaps in the reef) is 37\%. Consequently, the atoll is considered to be 'open' and allows penetration of tides and waves into the lagoon. Kench et al. (2006) show that there is no lag or attenuation of the tidal signal from water level records on reef flats across the atoll. Furthermore, an investigation of broadscale wave processes indicate

Table 1

Summary mean reef flat and maximum moat elevations on each reef platform.

\begin{tabular}{|c|c|c|c|c|c|c|c|c|}
\hline \multicolumn{3}{|c|}{ Dhakandhoo } & \multicolumn{3}{|c|}{ Hulhudhoo } & \multicolumn{3}{|c|}{ Thiladhoo } \\
\hline Location & $\begin{array}{l}\text { Max. Moat } \\
\text { elevation (m) }\end{array}$ & $\begin{array}{l}\text { Mean Reef } \\
\text { elevation (m) }\end{array}$ & Location & $\begin{array}{l}\text { Max. Moat } \\
\text { elevation (m) }\end{array}$ & $\begin{array}{l}\text { Mean Reef } \\
\text { elevation (m) }\end{array}$ & Location & $\begin{array}{l}\text { Max. Moat } \\
\text { elevation (m) }\end{array}$ & $\begin{array}{l}\text { Mean Reef } \\
\text { elevation (m) }\end{array}$ \\
\hline W & -1.13 & -0.61 & SW & -0.89 & -0.58 & SW & -1.14 & -0.55 \\
\hline $\mathrm{N}$ & -1.40 & -0.87 & NW & -1.16 & -0.93 & NW & -0.87 & -0.48 \\
\hline E & -1.13 & -0.61 & $\mathrm{NE}$ & -1.48 & -1.0 & $\mathrm{NE}$ & -0.98 & -0.57 \\
\hline $\mathrm{S}$ & -0.85 & -0.67 & SE & -0.77 & -0.60 & SE & -1.39 & -1.08 \\
\hline
\end{tabular}

All elevations are relative to mean sea level. Location of reefs shown in Fig. 1. 
a

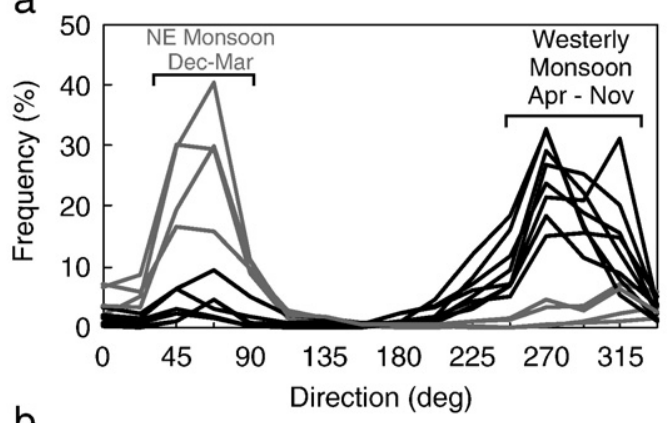

b
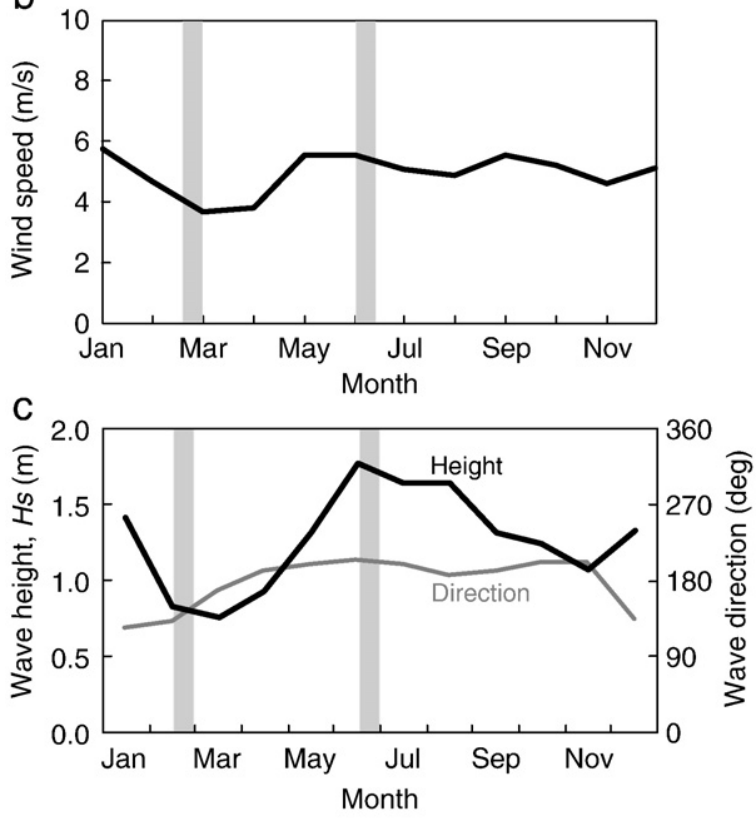

Fig. 2. Summary wind and wave climate averages for the Maldives. a) Thirty year mean monthly wind direction presented for each month. b) Thirty year mean monthly wind speed. Wind data from Maldivian Department of Meteorology (1995).c) Ten year mean monthly wave height and direction for the central Maldives. Source: Young (1999). Grey vertical bars denote periods of field experiments presented in this study.

that boundary wave energy is able to leak into the lagoon through larger passages but that the network of lagoonal reefs does extract energy from ocean swell (Kench et al., 2006). Furthermore, the significant fetch across the lagoon allows wind-generated waves to develop within the atoll system and affect downwind reefs (Kench et al., 2006).

It is important to note that this study examines the circulation patterns on top of a number of small and shallow reef platforms in the atoll. The reef platforms have a mean elevation approximately 0.5 to $1.0 \mathrm{~m}$ below mean sea level and together with the microtidal regime of the atoll (1.2 m mean spring tidal range) indicates that water depth across reefs is less than $2.0 \mathrm{~m}$. The combination of micro-tidal conditions and shallow platform water depth is commonly believed to indicate that deeper ocean circulation and tides have a negligible affect on shallow reef circulation processes (Hearn, 1999). The principle driver of hydrodynamic processes in such settings is believed to be incident waves (Roberts, 1975; Symonds et al., 1995; Hearn, 1999). At issue in this study, therefore, is the character of waves impacting each platform that may drive reef flat currents. As shown by Kench et al. (2006) for each individual reef platform incident wave energy is controlled by the relative presence or absence of boundary oceanic swell, the monsoonally forced wind-waves generated external and internal to the lagoon, as well as local sheltering factors promoted by proximity to other reefs.

\section{Methods}

Two 14-day experiments were conducted in June 2002 and February 2003 in order to characterise incident wave characteristics on the outer reef surfaces and current characteristics around the island shoreline during both the westerly and northeast monsoons. In each hydrodynamic experiment, Dobie wave gauges were deployed on the windward and leeward edges of each reef platform for sequential 4-5 day periods (Fig. 1c-d, Table 2 ) in order to identify the boundary wave conditions propagating onto the reef flat surfaces. The wave gauges sampled at $2 \mathrm{~Hz}$ and recorded 2048 samples (17.07 min) every half-hour. Water depths $(h)$ over the sensors were less than $2.5 \mathrm{~m}$ throughout the experiments and signal attenuation with depth was negligible.

Four InterOcean S4 electromagnetic current meters were deployed within $10 \mathrm{~m}$ of the island shoreline (in the moats) at locations around the island perimeter (Fig. 1c-e). Locations were selected to align with the dominant monsoonal wind directions (NE-SW and NW-SE) and capture energy on different exposures of the island shorelines. The current meters were mounted on stainless steel pods $0.2 \mathrm{~m}$ from the bed. Due to varying memory capacity of the S4 current meters differing setup routines were adopted. However, all instruments sampled at a minimum frequency of $2 \mathrm{~Hz}$ for $20 \mathrm{~min}$ each hour (Table 2). Due to equipment limitations experiments on each island were undertaken sequentially in five day periods.

Reef flat topography and elevation of instruments were surveyed using standard auto level techniques. Reef flat elevation varies between and within reef platforms (Table 2) ranging from $0.97 \mathrm{~m}$ below mean sea level (MSL) on the northwest edge of Thiladhoo to $1.56 \mathrm{~m}$ below MSL on the eastern edge of Dhakandhoo. During each experiment the position of the island beach was mapped in detail using a Trimble Geoexplorer III GPS with a horizontal positioning error of $\pm 1.5 \mathrm{~m}$. These results were combined with an earlier survey undertaken in February 2002 to examine seasonal adjustments of island beaches. Results of the seasonal beach changes are presented in Kench and Brander (2006a) and are discussed in the context of the hydrodynamic results in this study.

Estimates of significant wave height $(\mathrm{Hs})$, maximum wave height (Hmax) and significant wave period (Ts) were determined by zero down-crossing analysis. High frequency current records from each instrument were interrogated to identify errors. A number of lengths of data were identified on each instrument in which velocity and direction readings were too erratic to be sensibly caused by wave conditions on the reefs. Subsequent testing of the instruments indicated no fault with the instruments. Consequently, errant data was trimmed from the velocity records. Remaining velocity records were averaged over two minute intervals ( 240 samples) to generate an average current speed and direction. Current speed and direction was further split into sequential 12.5 hour blocks, encompassing both a rising and falling tide, and plotted as progressive vector plots to examine current patterns around island shorelines.

\section{Results}

\subsection{Dhakandhoo: west monsoon}

The June experiment was conducted under westerly wind conditions (Fig. 3a) with wind speeds of $3-4 \mathrm{~ms}^{-1}$ for the first 3 days increasing to $14 \mathrm{~ms}^{-1}$ during the last day of the experiment in response to a squall event (Fig. 3a). During the first 3 days of the experiment wave heights measured on the windward reef flat were characterised by $\mathrm{Hs}$ values ranging from $0.05 \mathrm{~m}$ at low tide stages up to $0.25-0.35 \mathrm{~m}$ at higher water levels (Fig. 3b). Significant wave period (Ts) was consistently around $7 \mathrm{~s}$ for all but the lowest water stages, where wave period increased to $>30 \mathrm{~s}$ (Fig. 3b). The absence of lagoon seiching (Kench et al., 2006) suggests this long period energy is related to 
Table 2

Summary instrument deployments and sampling design.

\begin{tabular}{|c|c|c|c|c|c|c|c|}
\hline \multirow[t]{2}{*}{ Location } & \multirow[t]{2}{*}{ Sensor } & \multicolumn{5}{|l|}{ Sampling } & \multirow{2}{*}{$\frac{\text { Reef elevation }}{(\mathrm{m} \text { below } \mathrm{msl})}$} \\
\hline & & Start & Stop & Rate & Burst length & Cycle time & \\
\hline \multicolumn{8}{|l|}{ Dhakandhoo June 2002} \\
\hline Windward reef flat & Dobie & $1200-20 / 6 / 02$ & $0818-24 / 6 / 02$ & $2 \mathrm{~Hz}$ & $18 \mathrm{~min}$ & $30 \mathrm{~min}$ & -1.29 \\
\hline Leeward reef flat & Dobie & $1200-20 / 6 / 02$ & $0818-24 / 6 / 02$ & $2 \mathrm{~Hz}$ & $18 \mathrm{~min}$ & $30 \mathrm{~min}$ & -1.59 \\
\hline W - shoreline & $\mathrm{S} 420 \mathrm{Mb}$ & $1200-20 / 6 / 02$ & $1839-24 / 6 / 02$ & $5 \mathrm{~Hz}$ & Continuous & - & -1.10 \\
\hline $\mathrm{N}$ - shoreline & $\mathrm{S} 41 \mathrm{Mb}$ & $1200-20 / 6 / 02$ & $1035-24 / 6 / 02$ & $2 \mathrm{~Hz}$ & $18 \mathrm{~min}$ & $30 \mathrm{~min}$ & -1.07 \\
\hline E - shoreline & S4 $20 \mathrm{Mb}$ & $1200-20 / 6 / 02$ & $1837-23 / 6 / 02$ & $2 \mathrm{~Hz}$ & Continuous & - & -0.78 \\
\hline S - shoreline & S4 $256 \mathrm{~K}$ & $1200-20 / 6 / 02$ & $1209-24 / 6 / 02$ & $2 \mathrm{~Hz}$ & $18 \mathrm{~min}$ & $60 \mathrm{~min}$ & -0.92 \\
\hline \multicolumn{8}{|l|}{ Dhakandhoo Feb 2003} \\
\hline Windward reef flat & Dobie & $1000-17 / 2 / 03$ & $1718-20 / 2 / 03$ & $2 \mathrm{~Hz}$ & $18 \mathrm{~min}$ & $30 \mathrm{~min}$ & -1.53 \\
\hline Leeward reef flat & Dobie & $1000-17 / 2 / 03$ & $1148-17 / 2 / 03$ & $2 \mathrm{~Hz}$ & $18 \mathrm{~min}$ & $30 \mathrm{~min}$ & -1.28 \\
\hline W - shoreline & S4 $20 \mathrm{Mb}$ & $1000-17 / 2 / 03$ & $1632-20 / 2 / 03$ & $5 \mathrm{~Hz}$ & Continuous & - & -1.02 \\
\hline $\mathrm{N}$ - shoreline & $\mathrm{S} 420 \mathrm{Mb}$ & $1000-17 / 2 / 03$ & $1636-20 / 2 / 03$ & $2 \mathrm{~Hz}$ & Continuous & - & -1.29 \\
\hline E - shoreline & S4 $20 \mathrm{Mb}$ & $1000-17 / 2 / 03$ & $1635-20 / 2 / 03$ & $2 \mathrm{~Hz}$ & Continuous & - & -0.78 \\
\hline S - shoreline & $\mathrm{S} 41 \mathrm{Mb}$ & $1000-17 / 2 / 03$ & $1634-20 / 2 / 03$ & $2 \mathrm{~Hz}$ & $18 \mathrm{~min}$ & $30 \mathrm{~min}$ & -0.92 \\
\hline \multicolumn{8}{|l|}{ Hulhudhoo June 2002} \\
\hline Windward reef flat & Dobie & $1000-25 / 6 / 02$ & $1348-28 / 6 / 02$ & $2 \mathrm{~Hz}$ & $18 \mathrm{~min}$ & $30 \mathrm{~min}$ & -1.29 \\
\hline Leeward reef flat & Dobie & $1000-25 / 6 / 02$ & $1348-28 / 6 / 02$ & $2 \mathrm{~Hz}$ & $18 \mathrm{~min}$ & $30 \mathrm{~min}$ & -1.64 \\
\hline SW - shoreline & $\mathrm{S} 41 \mathrm{Mb}$ & $1200-25 / 6 / 02$ & $1705-28 / 6 / 02$ & $2 \mathrm{~Hz}$ & $18 \mathrm{~min}$ & $30 \mathrm{~min}$ & -0.86 \\
\hline NW - shoreline & S4 $20 \mathrm{Mb}$ & $1200-25 / 6 / 02$ & $1733-28 / 6 / 02$ & $2 \mathrm{~Hz}$ & Continuous & - & -0.95 \\
\hline NE - shoreline & S4 $256 \mathrm{~K}$ & $1200-25 / 6 / 02$ & $1109-28 / 6 / 02$ & $2 \mathrm{~Hz}$ & $18 \mathrm{~min}$ & $60 \mathrm{~min}$ & -1.09 \\
\hline SE - shoreline & S4 $20 \mathrm{Mb}$ & $1200-25 / 6 / 02$ & $1637-28 / 6 / 02$ & $5 \mathrm{~Hz}$ & Continuous & - & -0.75 \\
\hline \multicolumn{8}{|l|}{ Hulhudhoo Feb 2003} \\
\hline Windward reef flat & Dobie & $1000-21 / 2 / 03$ & $1548-24 / 2 / 03$ & $2 \mathrm{~Hz}$ & $18 \mathrm{~min}$ & $30 \mathrm{~min}$ & -1.33 \\
\hline Leeward reef flat & Dobie & $1000-21 / 2 / 03$ & $1548-24 / 2 / 03$ & $2 \mathrm{~Hz}$ & $18 \mathrm{~min}$ & $30 \mathrm{~min}$ & -1.07 \\
\hline SW - shoreline & S4 $1 \mathrm{Mb}$ & $1000-21 / 2 / 03$ & $1448-24 / 2 / 03$ & $2 \mathrm{~Hz}$ & $18 \mathrm{~min}$ & $30 \mathrm{~min}$ & -0.77 \\
\hline NW - shoreline & S4 $20 \mathrm{Mb}$ & $1000-21 / 2 / 03$ & $1453-24 / 2 / 03$ & $2 \mathrm{~Hz}$ & Continuous & - & -1.10 \\
\hline NE - shoreline & $\mathrm{S} 420 \mathrm{Mb}$ & $1000-21 / 2 / 03$ & $1444-24 / 2 / 03$ & $5 \mathrm{~Hz}$ & Continuous & - & -1.12 \\
\hline SE - shoreline & S4 $20 \mathrm{Mb}$ & $1000-21 / 2 / 03$ & $1454-24 / 2 / 03$ & $2 \mathrm{~Hz}$ & Continuous & - & -0.88 \\
\hline \multicolumn{8}{|l|}{ Thiladhoo June 2002} \\
\hline Windward reef flat & Dobie & $1000-29 / 6 / 02$ & $1348-2 / 7 / 02$ & $2 \mathrm{~Hz}$ & $18 \mathrm{~min}$ & $30 \mathrm{~min}$ & -0.96 \\
\hline Leeward reef flat & Dobie & $1000-29 / 6 / 02$ & $1348-2 / 7 / 02$ & $2 \mathrm{~Hz}$ & $18 \mathrm{~min}$ & $30 \mathrm{~min}$ & -2.26 \\
\hline SW - shoreline & S4 $256 \mathrm{~K}$ & $1200-29 / 6 / 02$ & $1018-2 / 7 / 02$ & $2 \mathrm{~Hz}$ & $18 \mathrm{~min}$ & $60 \mathrm{~min}$ & -1.00 \\
\hline NW - shoreline & S4 $20 \mathrm{Mb}$ & $1200-29 / 6 / 02$ & $1700-2 / 7 / 02$ & $2 \mathrm{~Hz}$ & Continuous & - & -0.89 \\
\hline NE - shoreline & S4 $1 \mathrm{Mb}$ & $1200-29 / 6 / 02$ & $1405-2 / 7 / 02$ & $2 \mathrm{~Hz}$ & $18 \mathrm{~min}$ & $30 \mathrm{~min}$ & -0.79 \\
\hline SE - shoreline & $\mathrm{S} 420 \mathrm{Mb}$ & $1200-29 / 6 / 02$ & $1700-2 / 7 / 02$ & $5 \mathrm{~Hz}$ & Continuous & - & -1.18 \\
\hline \multicolumn{8}{|l|}{ Thiladhoo Feb 2003} \\
\hline Windward reef flat & Dobie & $1000-21 / 2 / 03$ & $0948-24 / 2 / 03$ & $2 \mathrm{~Hz}$ & $18 \mathrm{~min}$ & $30 \mathrm{~min}$ & -1.80 \\
\hline Leeward reef flat & Dobie & $1000-21 / 2 / 03$ & $0948-24 / 2 / 03$ & $2 \mathrm{~Hz}$ & $18 \mathrm{~min}$ & $30 \mathrm{~min}$ & -1.28 \\
\hline SW - shoreline & S4 $20 \mathrm{Mb}$ & $1000-25 / 2 / 03$ & $0932-28 / 2 / 03$ & $5 \mathrm{~Hz}$ & Continuous & - & -0.74 \\
\hline NW - shoreline & $\mathrm{S} 420 \mathrm{Mb}$ & $1000-25 / 2 / 03$ & $0910-28 / 2 / 03$ & $2 \mathrm{~Hz}$ & Continuous & - & -0.85 \\
\hline NE - shoreline & S4 $20 \mathrm{Mb}$ & $1000-25 / 2 / 03$ & $1318-28 / 2 / 03$ & $2 \mathrm{~Hz}$ & Continuous & - & -0.94 \\
\hline SE - shoreline & $\mathrm{S} 41 \mathrm{Mb}$ & $1000-25 / 2 / 03$ & $0935-28 / 3 / 08$ & $2 \mathrm{~Hz}$ & $18 \mathrm{~min}$ & $30 \mathrm{~min}$ & -0.91 \\
\hline
\end{tabular}

Location of instruments shown in Fig. 1.

generation of long waves as a result of wave groups interacting with the reef flat at low water stages. During the final day of the deployment $H$ s values increased to a peak of $0.42 \mathrm{~m}$. Maximum wave heights (Hmax) increased from peak values of $0.5 \mathrm{~m}$ at the start of the experiment to $0.72 \mathrm{~m}$ associated with the squall event (Fig. $3 \mathrm{~b}$ ). Wave characteristics exhibit clear tidal modulation on the windward reef flat with peak wave heights (Hs and Hmax) occurring at higher water stages.

Wave characteristics on the leeward reef flat are only weakly modulated by tidal level (absence of significant oscillation in wave characteristics at tidal frequencies, Fig. 3c) suggesting recorded waves were not limited by water depth at this location. Significant wave height $(\mathrm{Hs}$ ) ranged from $0.2 \mathrm{~m}$ at the start of the experiment to $0.45 \mathrm{~m}$ at the end of the experiment, which is similar to the windward reef flat, with Ts values of $10-11$ s (Fig. 3c). Furthermore, Hmax values peak at $0.45 \mathrm{~m}$ at the beginning and $0.65 \mathrm{~m}$ toward the end of the experiment (Fig. 3c).

Averaged current records during the westerly monsoon show clear tidal modulation with peak measured currents occurring at lower tidal stages at all instrument locations (Fig. 4a-d). There is considerable variation in the magnitude of currents around the island shoreline. The windward (western) instrument exhibited peak currents of $0.38-0.40 \mathrm{~ms}^{-1}$ at low tide with velocities in excess of $0.30 \mathrm{~ms}^{-1}$ sustained for up to $2 \mathrm{~h}$ around lowest tidal stages (Fig. 4c). The windward velocity signature also exhibits a second (lower) velocity peak of between 0.20 and $0.25 \mathrm{~ms}^{-1}$ at high tide (Fig. 4c) whereas velocities fall below $0.2 \mathrm{~ms}^{-1}$ at mid-tide stages.

The leeward (eastern) end of Dhakandhoo exhibited the second largest current speeds (Fig. 4a) peaking at $0.31 \mathrm{~ms}^{-1}$ approaching the first low tide and $0.22 \mathrm{~ms}^{-1}$ in subsequent low tide records. Weakest currents were observed at mid-tide stages at $0.01 \mathrm{~ms}^{-1}$ (Fig. 4a). The northern lateral flank of the island (with respect to wind direction) also exhibited peak current velocities of $\sim 0.26-0.28 \mathrm{~ms}^{-1}$ around lower water stages and minor secondary velocity peaks $\left(\sim 0.15 \mathrm{~ms}^{-1}\right)$ during the higher low tide periods (Fig. 4d). The southern shoreline of Dhakandhoo experienced the lowest magnitude velocity conditions. In the first 2 days of measurement velocities peaked at $0.17 \mathrm{~ms}^{-1}$ (Fig. 4b), although they increased (as did all records) on the last day $\left(\sim 0.22 \mathrm{~ms}^{-1}\right.$, Fig. $\left.4 \mathrm{~b}\right)$ in association with the squall event.

A notable feature of the current records is the near uniform direction of currents at each site, although the direction of currents varies 

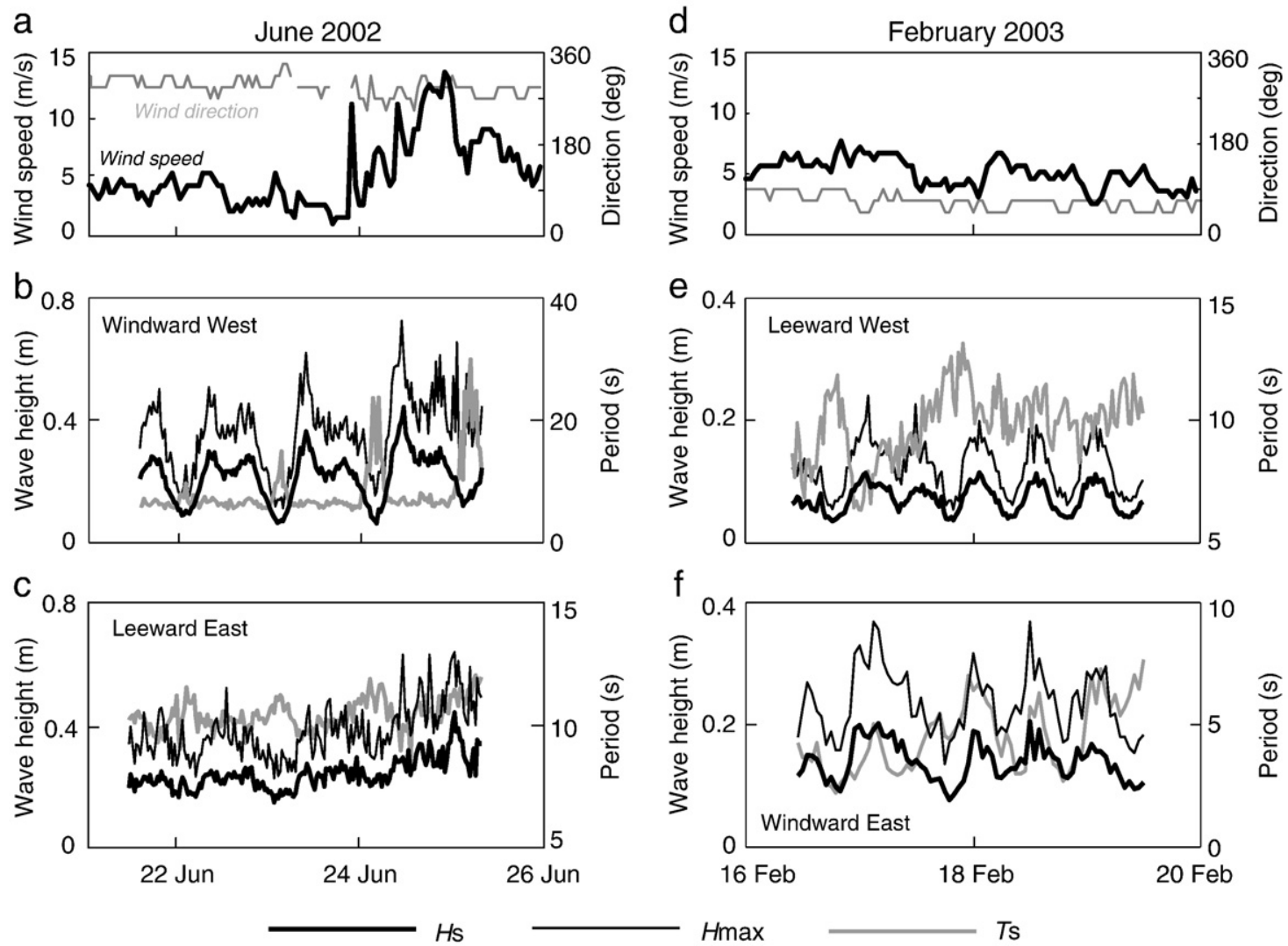

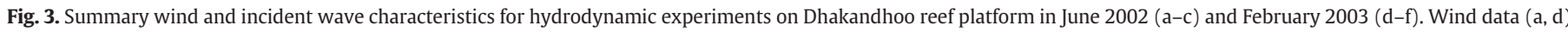
obtained from the Hulule meteorological station, Male. Locations of wave data collection shown on Fig. 1.

between instrument locations (Fig. 4a-d). There is a shift in current direction from south to east at the southern shoreline in the last day of the deployment (Fig. 4c). However, most records exhibit small variations in current direction and there is no clear evidence of modulation of current direction with tidal stage.

\subsection{Dhakandhoo: northeast monsoon}

The February 2003 experiment was undertaken under the influence of winds from the east-northeast with wind speeds between 4 and $7.5 \mathrm{~ms}^{-1}$ (Fig. 3d). Wave conditions on the Dhakandhoo reef flat surface were considerably lower in energy than the westerly monsoon experiment. Peak $\mathrm{Hs}$ values ranged from $0.21 \mathrm{~m}$ on the windward outer reef flat to $0.10 \mathrm{~m}$ on the leeward (western reef flat, Fig. 3e, f). Maximum wave heights (Hmax) ranged up to $0.37 \mathrm{~m}$ on the windward (east) and $0.24 \mathrm{~m}$ on the leeward (west) reef flat. The significant wave period was markedly different at opposite sides of the reef platform with larger waves on the windward reef flat having periods ranging from 4 to $7 \mathrm{~s}$ and smaller waves on the leeward reef flat having Ts values between 8 and 13 s (Fig. 3e, f).

Like the westerly monsoon, peak currents occurred on the windward (eastern, $0.33 \mathrm{~ms}^{-1}$ ) and leeward (western, $0.22-0.25 \mathrm{~ms}^{-1}$ ) locations of the Dhakandhoo shoreline (Fig. 4e, g). Of note, windward peaks in velocity appear in phase with tidal stage, whereas velocity maxima occur at lower water levels on the leeward (western) and northern shoreline (Fig. 4g, h). The lateral flanks of the island (north and south) had considerably lower velocities peaking at $0.14-0.15 \mathrm{~ms}^{-1}$.

Currents exhibit a relatively constant direction in the northeast experiment (Fig. 4e-f). There is no clear association between tidal stage and current direction, although high tide stages do appear to promote a small shift in current flow from the north-northwest to the north at the western shoreline (Fig. 4h). The southern shoreline also exhibits a reversal in current direction for the last 2 days of the experiment (from an average of $150^{\circ}$ to $0^{\circ}-20^{\circ}$, Fig. $4 \mathrm{f}$ ).

\subsection{Dhakandhoo: summary current patterns}

A feature of the current data is the consistency in direction of currents at each shoreline location. Progressive vector plots summarise the differences in current direction between shoreline locations and between the two monsoon seasons (Fig. 5). A number of distinct features of the current patterns are notable. First, progressive vectors constructed for the 12.5 hour periods indicate currents are predominantly unidirectional during both experiments. Under westerly monsoon conditions flow at the western end of the island is to the south while currents on the lateral flanks and leeward end (east) generally flow to the east-southeast (Fig. 5). During the northeast monsoon conditions current patterns were similar at the west and southern sides of the island, flowing to the south and southeast respectively. However, progressive vectors at the windward (east) and northern shoreline shifted orientation by approximately $100^{\circ}$ to flow south-southwest and north-northeast on the eastern and northern shorelines respectively (Fig. 5).

\subsection{Hulhudhoo: west monsoon}

Winds during the Hulhudhoo deployment were consistently from the northwest at speeds typically ranging from 5 to $7 \mathrm{~ms}^{-1}$ (Fig. 6a). Wave conditions at the windward outer reef flat on Hulhudhoo ranged up to $\mathrm{Hs}=0.24 \mathrm{~m}$ (mean of $\sim 0.2 \mathrm{~m}$ ) with $\mathrm{Ts}$ of $5-8 \mathrm{~s}$ (Fig. 6b). The leeward reef edge experienced slightly larger wave height conditions, with peak and mean $H s$ values of $0.3 \mathrm{~m}$ and $0.25 \mathrm{~m}$ respectively. These waves possessed longer wave period than the windward locations ( $T \mathrm{~s}=10-11 \mathrm{~s}$, Fig. 6c). Maximum recorded wave heights ranged up to $0.45 \mathrm{~m}$ and $0.55 \mathrm{~m}$ on windward and leeward reef flat locations 


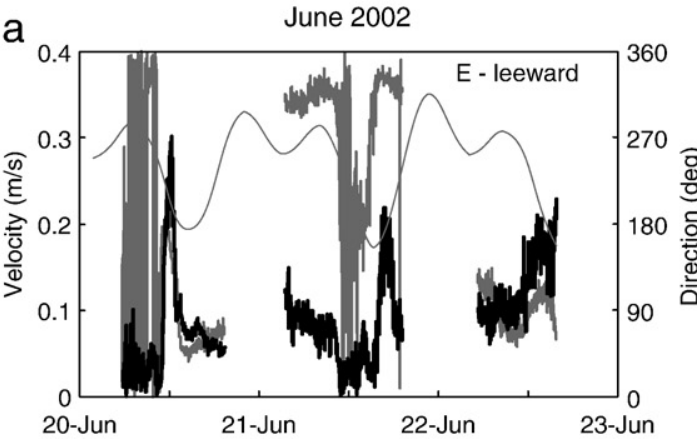

b
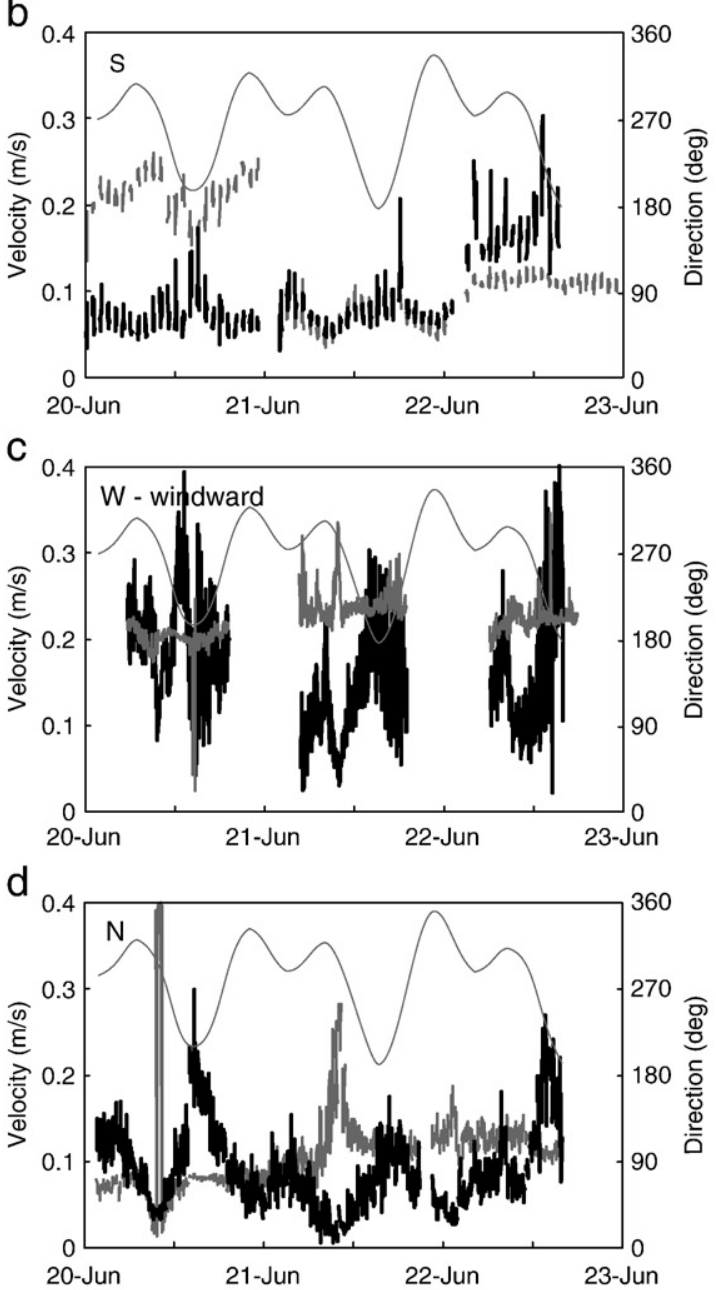
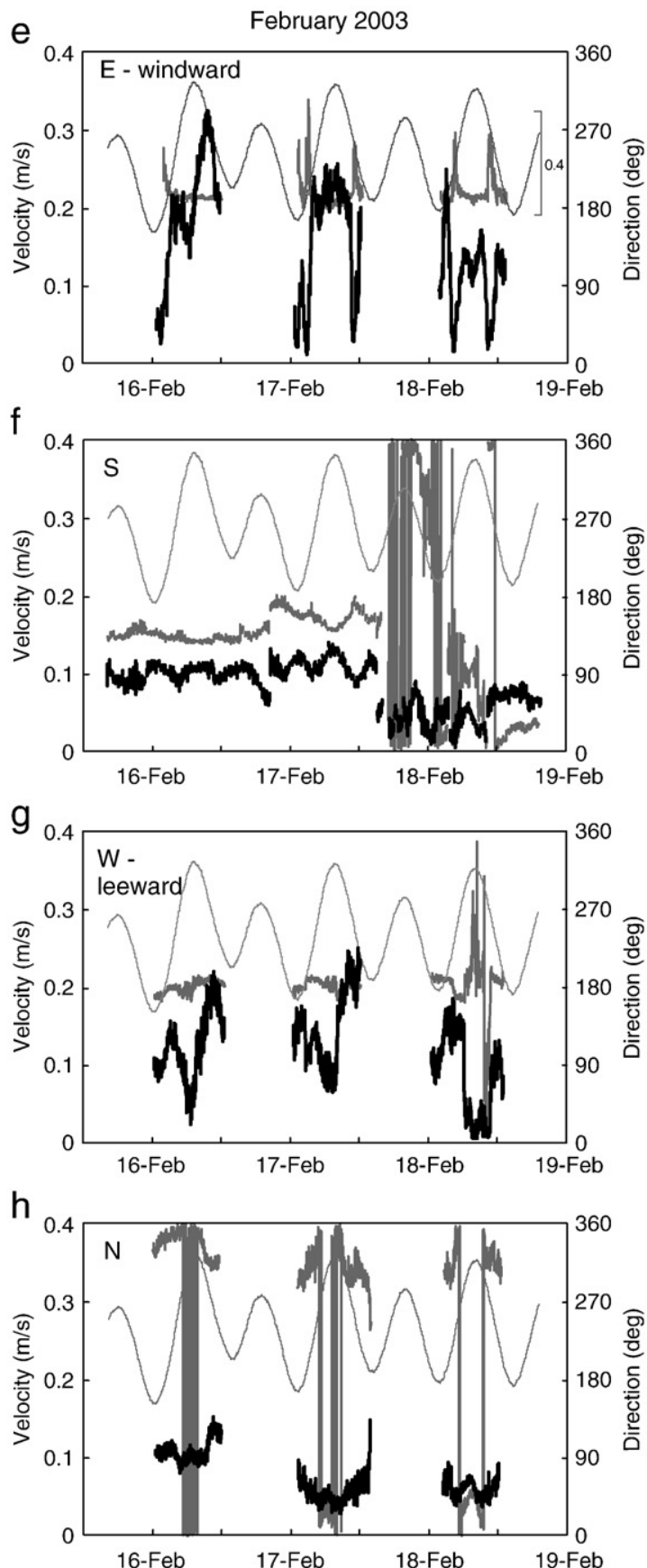

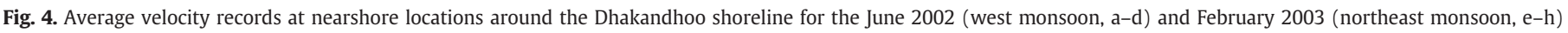

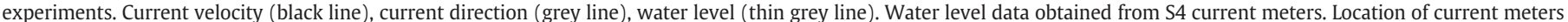
shown on Fig. 1.

respectively. There was a notable absence of tidal modulation of the wave record during this deployment (Fig. 6b, c).

The windward westerly shoreline locations (NW and SW) show clear tidal modulation in mean current velocity with current maxima of $0.3 \mathrm{~ms}^{-1}$ (NW, Fig. 7b) and $0.35 \mathrm{~ms}^{-1}$ (SW, Fig. 7a) at lowest tidal stages. A water level threshold is apparent ( 1.1 m tidal elevation) at which mean currents become significantly stronger at both these locations (Fig. 7a, b) allowing increased velocity levels to occur for several hours around lowest tidal levels. Lower amplitude peaks in mean current are also apparent at these locations during the higher low tide stages, although the velocity increases to only $0.10-0.15 \mathrm{~ms}^{-1}$ at these times (Fig. 7a, b). Other than low water levels mean currents are less than $0.1 \mathrm{~ms}^{-1}$. Peak velocities at the island shoreline were recorded at the south-western $\left(\sim 0.32-0.35 \mathrm{~ms}^{-1}\right)$ and north-eastern $(0.30-$ $0.38 \mathrm{~ms}^{-1}$, Fig. 7c) locations. Despite the truncated nature of the velocity record at the northeast shoreline velocity maxima appear to correspond with both high and lower water phases (Fig. 7c). The southeast shoreline location experienced the most subdued velocity signature with currents ranging from 0.07 to $0.20 \mathrm{~ms}^{-1}$ (Fig. 7d). At this location there is weak modulation of the velocity signature with tidal stage.

The direction of currents remains consistent throughout the measurement period and shows little evidence of tidal modulation at most locations (Fig. 7a-d). The greatest degree of tidal modulation occurs at the southwest shoreline where currents move from the northwest $\left(\sim 330^{\circ}\right)$ to west $\left(250^{\circ}-270^{\circ}\right)$ directions during the first 


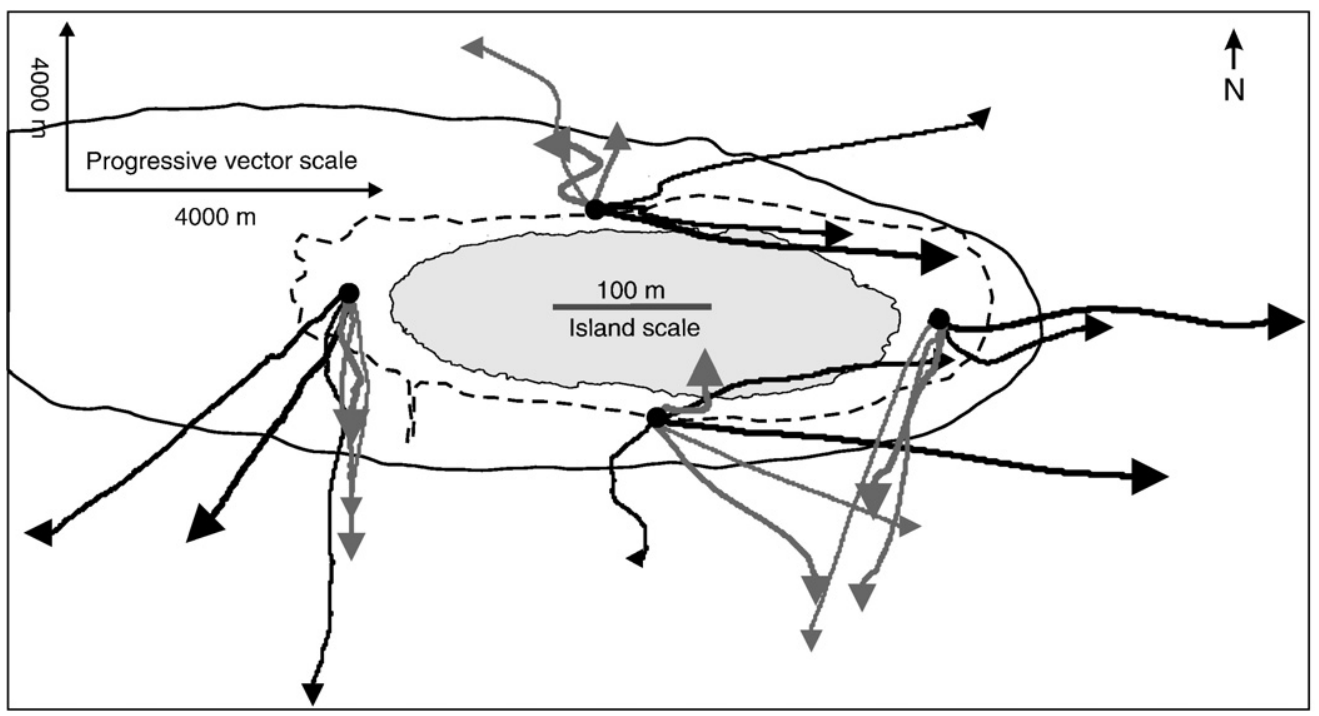

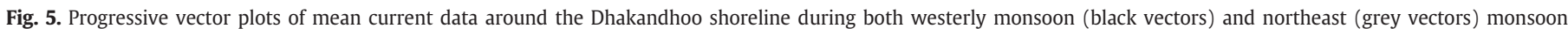

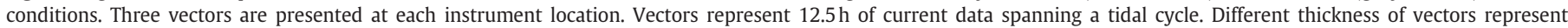
equivalent 12.5 hour time periods at each nearshore location.

two low tide periods. However, this shift is absent during the third day of the experiment (Fig. 7a). At the northwest shoreline there is a shift in current direction from the NNE at the start of the current record to the east by the end of the experiment (Fig. 7c).

\subsection{Hulhudhoo: northeast monsoon}

Winds blew consistently from the northeast during the February 2003 experiment with speeds ranging from 3 to $7 \mathrm{~ms}^{-1}$ (Fig. 6d).
Wave conditions during the northeast monsoon experiment were considerably lower in magnitude from those experienced in the westerly monsoon (Fig. 6e-f). At the outer windward reef flat (NE) Hs values ranged from $0.12 \mathrm{~m}$ at the start and decrease to $0.06 \mathrm{~m}$ toward the end of the experiment with Ts of 4-6s (Fig. 6f). At the leeward reef flat location $H s$ values were less than $0.1 \mathrm{~m}$ and decreased to $\sim 0.05 \mathrm{~m}$ during the experiment, with Ts values of 7-10 s (Fig. 6e). Maximum recorded wave heights were $0.19 \mathrm{~m}$ and $0.28 \mathrm{~m}$ on the windward and leeward reef edge respectively (Fig. 6e, f).
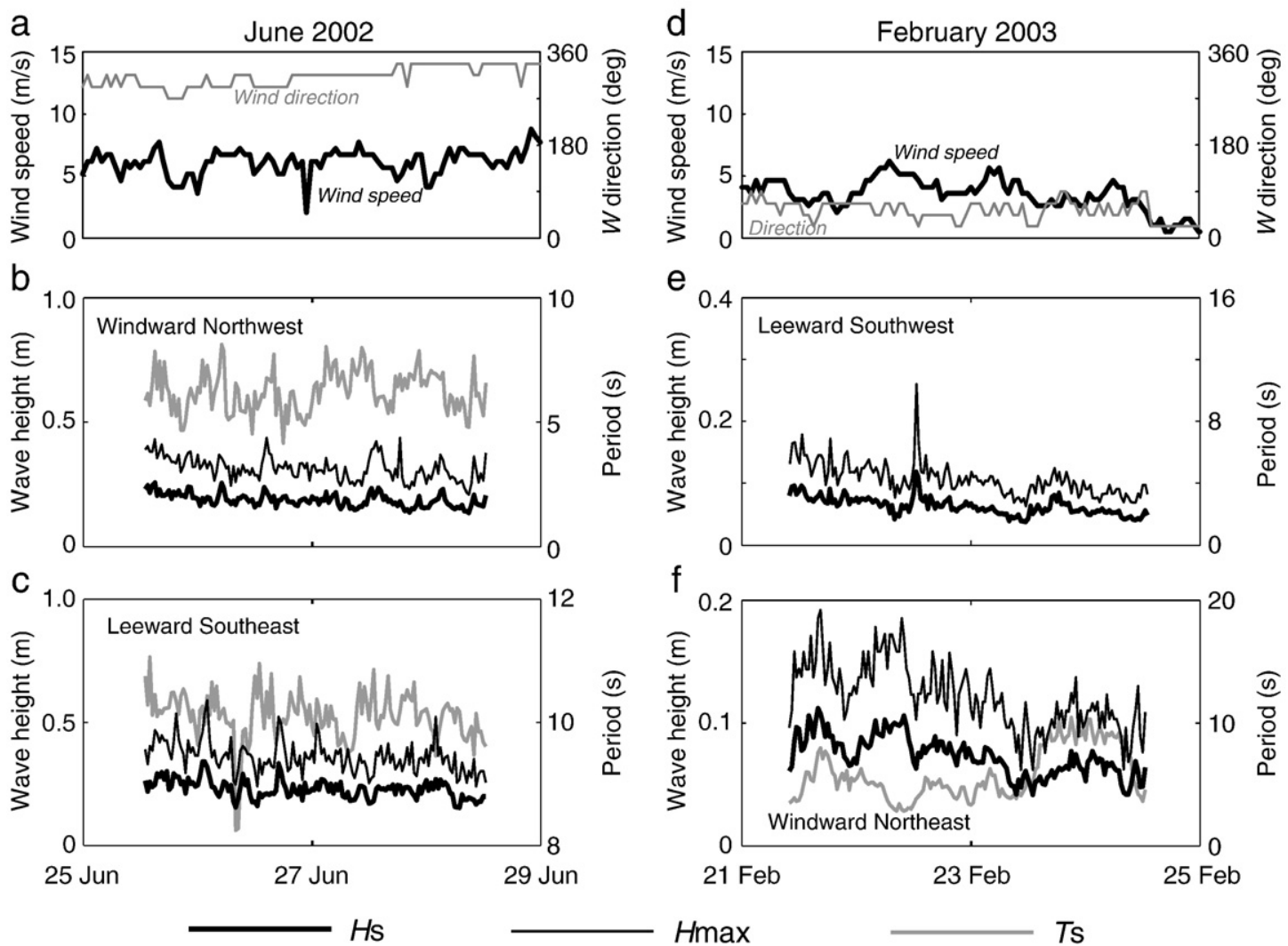

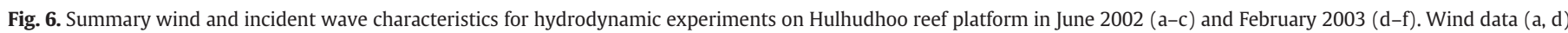
obtained from the Hulule meteorological station, Male. Locations of wave data collection also shown on Fig. 1. 
Velocity at the windward shoreline (NE, Fig. $7 \mathrm{~g}$ ) peaked at $0.18 \mathrm{~ms}^{-1}$ at lower tidal stages, although the truncated records make such determination difficult. The windward location experienced mean current velocities of $0.05 \mathrm{~ms}^{-1}$ at the beginning of the experiment increasing to $\sim 0.10 \mathrm{~ms}^{-1}$ at the end of the deployment (Fig. $7 \mathrm{~g}$ ). Currents on the lateral flanks of the island (NW and SE locations, which are approximately $90^{\circ}$ to the NE monsoon winds) exhibit the strongest flows peaking at $0.35 \mathrm{~ms}^{-1}$ (NW, Fig. 7f) and $0.32 \mathrm{~ms}^{-1}$ (SE, Fig. 7h). Of note, the northwest shoreline experienced sustained velocities of $\sim 0.20 \mathrm{~ms}^{-1}$ for the first 3 days of the experiment reducing to $0.14 \mathrm{~ms}^{-1}$ toward the end of the experiment (Fig. 7f). The southeast shoreline location experienced larger oscillations in velocity, peaking at mid to low tide stages (Fig. 7h). At the leeward shoreline (southwest) mean velocities were $0.08-0.10 \mathrm{~ms}^{-1}$ during the first 2 days of the experiment, increasing gradually to $0.14 \mathrm{~ms}^{-1}$ in the middle of the experiment, before declining to $<0.05 \mathrm{~ms}^{-1}$ (Fig. 7e). There was little modulation of the velocity signature at this leeward location.

The direction of currents during the northeast monsoon experiment show little evidence of tidal modulation. However, current direction appears more variable in this experiment with oscillations of up to $90^{\circ}$ observed (Fig. 7e-h). Of further note is the change in current direction on the southwest shoreline from the south-southwest to east in the last day of the deployment.

\subsection{Hulhudhoo: summary current patterns}

Progressive vector plots of current flow during the westerly monsoon indicate that near shoreline currents are unidirectional
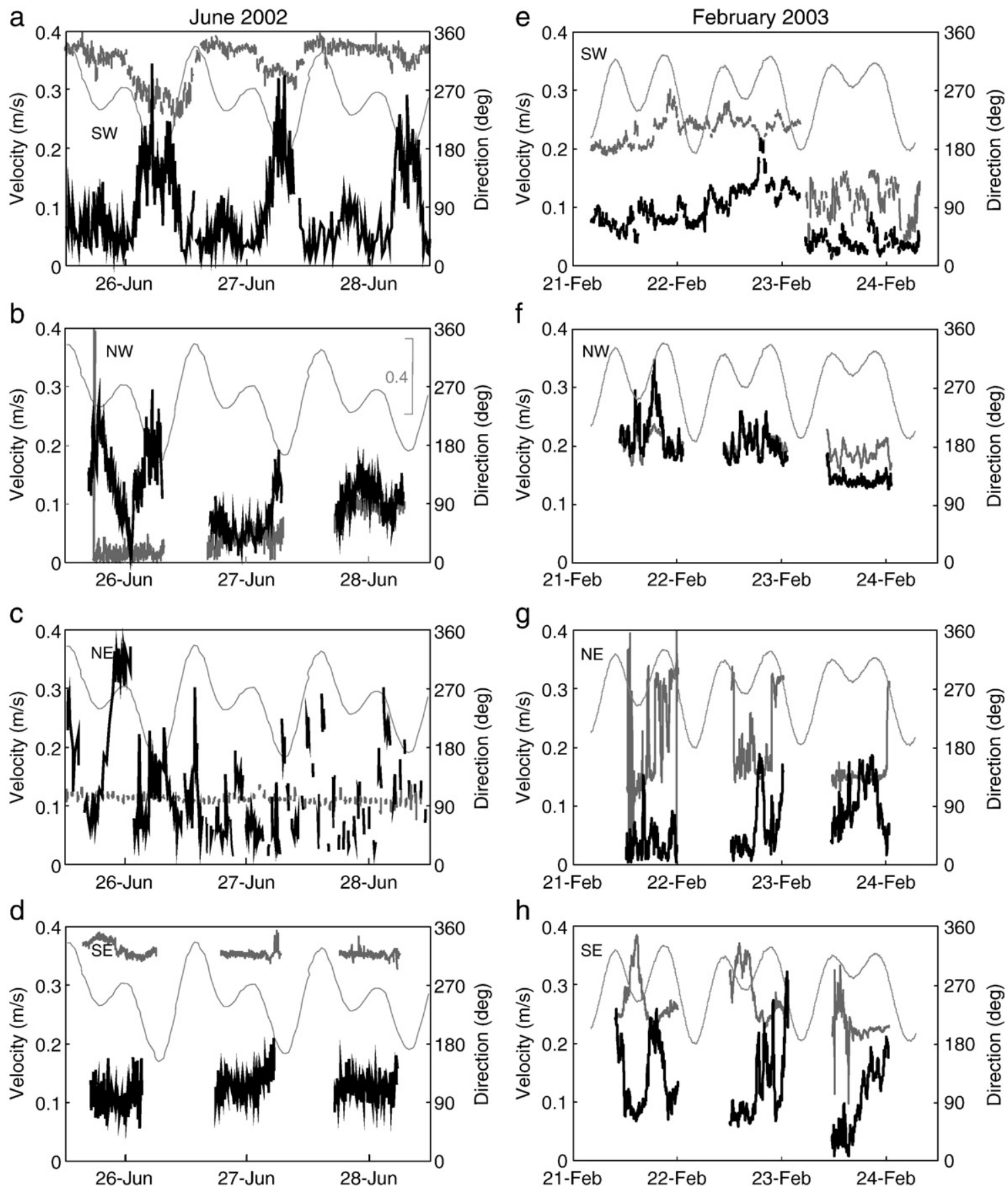

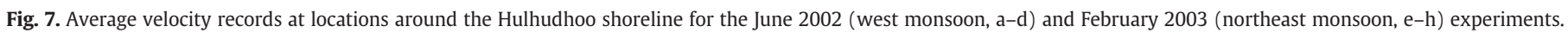
Current velocity (black line), current direction (grey line), water level (thin grey line). Water level data obtained from S4 current meters. Location of current meters shown on Fig. 1. 
(Fig. 8). During the westerly monsoon vectors indicate flow from the south to north and northeast, with water draining off the reef surface toward the north-northeast. Flow directions are significantly different during the northeast monsoon. Progressive vectors at the northeast shoreline are the only ones to display any modulation at tidal frequencies with all other locations exhibiting unidirectional current flow. Of note, progressive vectors at the northwest shoreline flow toward the south, representing a 180 degree reversal in flow direction from the westerly monsoon (Fig. 8). At the southeast and southwest shoreline locations progressive vectors indicate flow toward the southwest and south respectively. These flow directions represent an approximate 90-120 degree shift in flow direction from the westerly monsoon (Fig. 8).

\subsection{Thiladhoo: west monsoon}

The June 2002 experiment at Thiladhoo was conducted under the influence of west-northwest winds with speeds of $4-8 \mathrm{~ms}^{-1}$ (Fig. 9a). Wave characteristics propagating across the outer windward reef flat at Thiladhoo possessed maximum $H$ s values of $0.2 \mathrm{~m}$ (mean $0.12 \mathrm{~m}$, which declined through the experiment), $\mathrm{Ts}$ of $5-7 \mathrm{~s}$ and Hmax values ranging from $0.38 \mathrm{~m}$ at the beginning to $0.2 \mathrm{~m}$ toward the end of the deployment (Fig. 9b). Of note, the wave conditions on the windward reef edge exhibited marked tidal modulation. Leeward wave conditions were characterised by waves with $H s=0.1 \mathrm{~m}$, Ts $=7-10 \mathrm{~s}$ and Hmax values $0.15-0.25 \mathrm{~m}$ (Fig. 9c).

Maximum mean current velocities were recorded at the southwestern island shoreline peaking at $0.20 \mathrm{~ms}^{-1}$, with mean velocity throughout the deployment generally less than $0.1 \mathrm{~ms}^{-1}$ (Fig. 10a). At this location there is a weak modulation of the velocity signature with lower tides associated with larger velocities. At all other shoreline locations currents were generally $0.10 \mathrm{~ms}^{-1}$ or less and only weakly modulated with the tide (Fig. 10b-d). Weakest currents were recorded at the NW shoreline (Fig. 10b).

As with other experiments the direction of currents varies between shoreline locations but remains relatively consistent at each location throughout the deployment (Fig. 10a-d). There are small shifts $\left(10-20^{\circ}\right)$ in current direction between days with no apparent tidal modulation of current direction.

\subsection{Thiladhoo: northeast monsoon}

North to northeast winds with speeds of $1-4 \mathrm{~ms}^{-1}$ prevailed during the February 2003 experiment at Thiladhoo (Fig. 9d). Wave characteristics were lower in magnitude during the northeast as opposed to westerly monsoon experiments (Fig. 9e-f). In general, wave height was larger at the leeward outer reef flat location. However, at both the windward and leeward locations $H s$ values were generally less than $0.1 \mathrm{~m}$, although there was an increase toward the end of the experiment to $0.18 \mathrm{~m}$ at the leeward and $0.11 \mathrm{~m}$ at the windward location. Wave period was consistently between 7 and $9 \mathrm{~s}$ at both locations (Fig. 9e, f). Peak $H_{\max }$ values were $0.16 \mathrm{~m}$ (mean $\sim 0.11 \mathrm{~m}$ ) and $0.32 \mathrm{~m}$ (mean $0.14 \mathrm{~m}$ ) at windward and leeward locations respectively.

Measured current velocities at all stations are generally low in magnitude $\left(<0.10 \mathrm{~ms}^{-1}\right)$, peaking toward the end of the deployment at $0.16 \mathrm{~ms}^{-1}$ at the windward (NE) and northwest shorelines (Fig. 10e-h). There are a number of notable features of these velocity records. First, all records show current pulses at subtidal (2-3 hour periods). Second, windward (NE and NW) locations exhibit an increase in current velocity in the latter stages of the experiment (Fig. 10f, g). Third, leeward (S and SW) locations exhibit more subdued velocity oscillations. Fourth, velocities at leeward locations (SE and SW) decline at the end of the experiment, at the same time as velocities increase at windward shorelines (Fig. 10e-h).

Like the westerly monsoon period current direction during the northeast monsoon is characterised by lack of tidal modulation, differences in direction between shoreline locations and relative consistency in direction at each site (Fig. 10e-f). The strongest evidence for any tidal influence on current direction occurs at the northwest shoreline where currents shift from southwest flow to northerly flow during the rising stages of the tide in the first 2 days of the experiment. Such change is not observed on subsequent days (Fig. 10f).

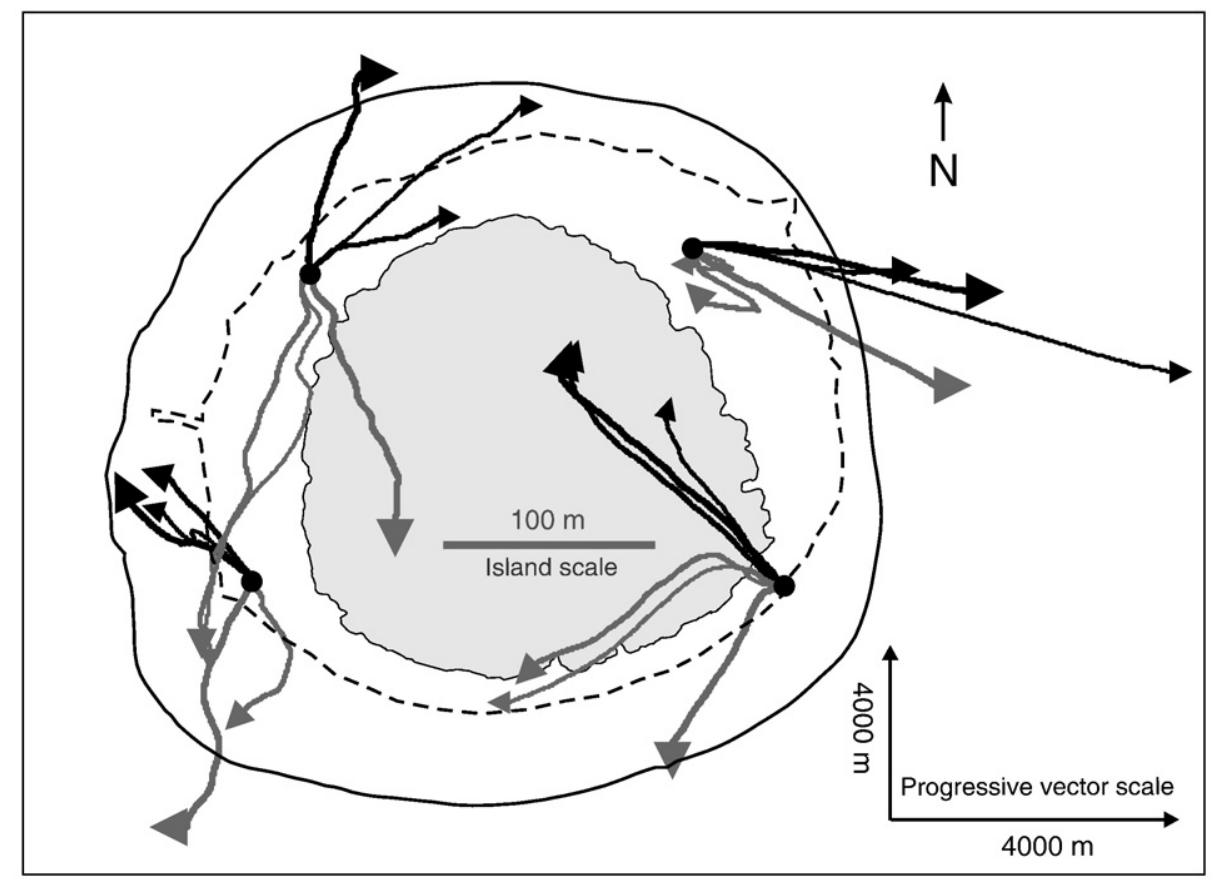

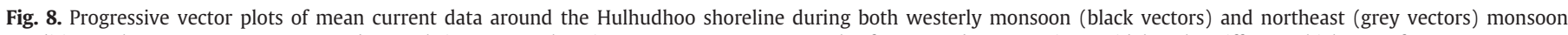

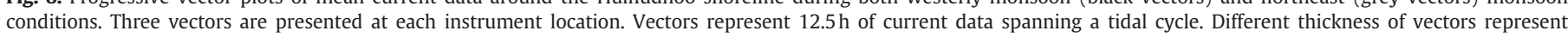
equivalent 12.5 hour time periods at each nearshore location. 
a

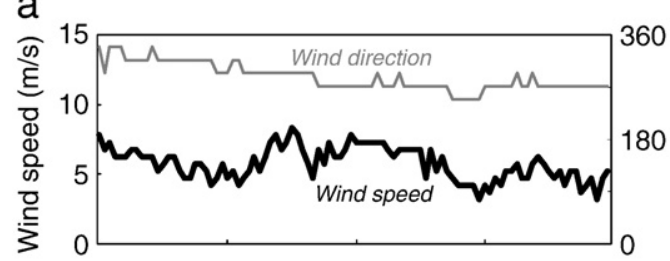

$\mathrm{b}$

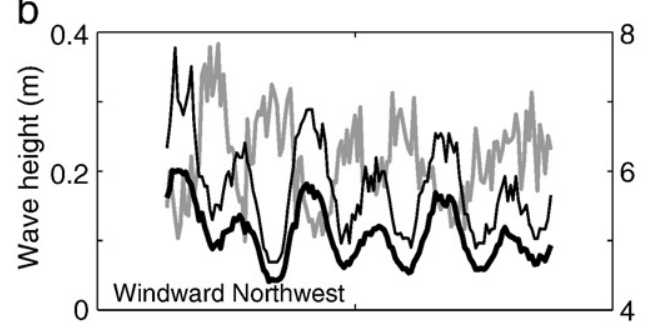

C

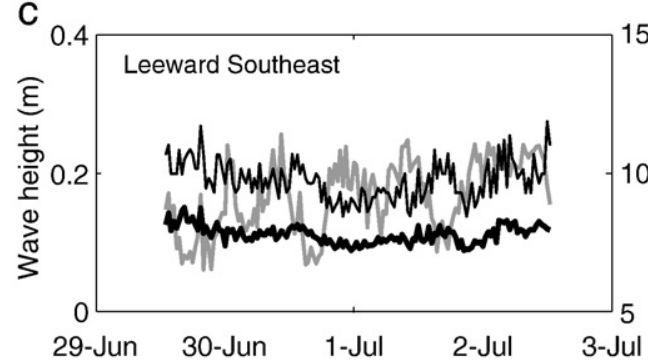

d

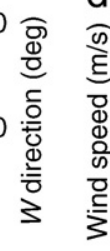

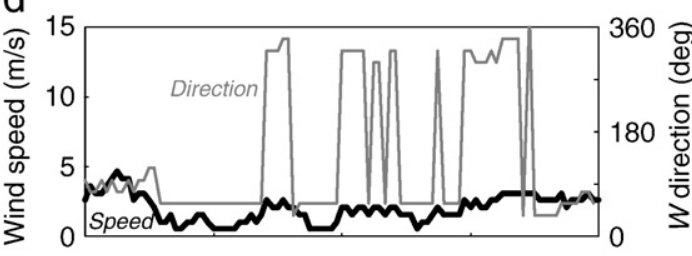

e

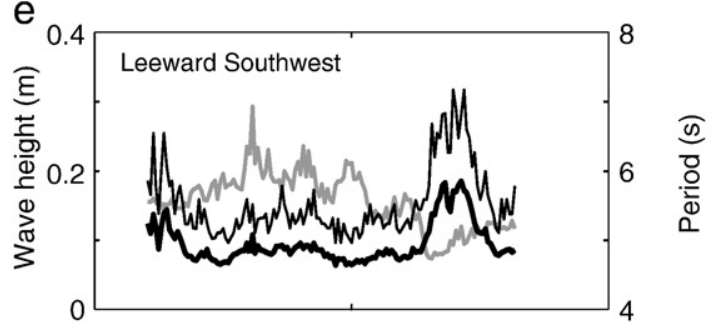

$\mathrm{f}$
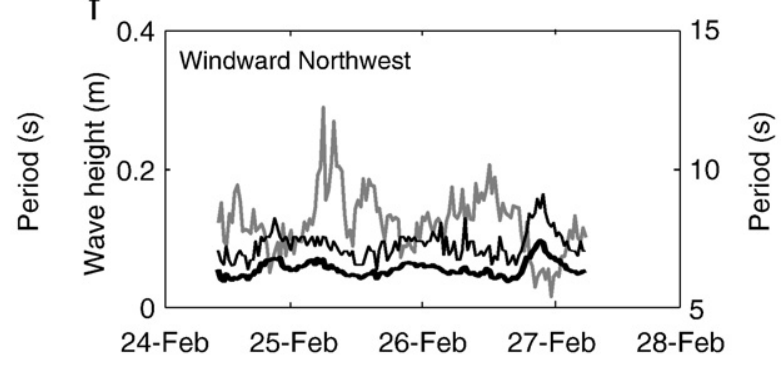

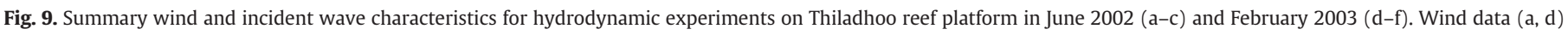
obtained from the Hulule meteorological station, Male. Locations of wave data collection shown on Fig. 1.

\subsection{Thiladhoo: summary current patterns}

Progressive vectors representing flow patterns at each current meter location indicate currents were unidirectional during both experiments. Under westerly monsoon conditions currents generally flow to the east-southeast (NE and SW shorelines) or southsoutheast (SE shoreline, Fig. 11). Flow at the northwest shoreline is to the southwest (Fig. 11). Under northeast monsoon conditions current patterns remain the same at the northwest shoreline. However, progressive vectors are deflected $\sim 40^{\circ}$ to the southeast at the northeast shoreline. Largest changes in current direction are observed at the SE shoreline where currents flow toward the northnortheast (a change in orientation of vectors of up to $180^{\circ}$ compared with the westerly monsoon) and SW shoreline where currents flow north-northeast (a 45-90 degree shift to the north compared with the westerly monsoon, Fig. 11).

\section{Discussion}

Observations of incident outer reef flat wave conditions and nearshore current measurements provide insights into the driving mechanisms of reef flat currents and resultant circulation patterns influencing island shorelines. Experiments also highlight the role of the monsoons in modulating reef platform circulation which have significant implications for island beach morphodynamics.

Flow across coral reefs is governed by tides, wind and wave breaking at the reef edge (Roberts, 1975; Roberts and Suhayda, 1983; Symonds, et al, 1995; Lugo-Fernández et al., 1998a,b). In general, the relative importance of tides increases with increasing tidal range, or in microtidal settings as wind and wave energy decline (Pickard, 1986; Lugo-Fernández et al., 2004). In South Maalhosmadulu atoll the micro-tidal regime and lack of tidal modulation of current patterns (Figs. 5, 8 and 11) imply the role of tides in generating currents across the study platforms is limited. Wind conditions during all experi- ments were consistent (in direction and speed) with historic wind conditions (Figs. 2, 3, 6 and 9) with west-northwest and northeast winds occurring during the June and February experiments respectively. The influence of wind is clearly seen in the latter stages of the first experiment on Dhakandhoo Island where a squall event increased wind speeds to $11-14 \mathrm{~ms}^{-1}$ (Fig. 3a). Maximum wave heights recorded during this event approached $0.75 \mathrm{~m}$ (Fig. 3b) and there was a notable increase in current velocity through the event (Fig. 4c). Consequently, wind and wave energy impacting the reef platforms are considered the main mechanisms generating reef flat currents at the study sites.

\subsection{Reef flat wave conditions}

Windward and leeward wave observations from the outer reef flat locations on each study island exhibit marked differences in incident wave height between monsoon periods. The westerly monsoon delivered largest waves to reefs with maximum $H s$ values of $0.45 \mathrm{~m}$, $0.25 \mathrm{~m}$ and $0.2 \mathrm{~m}$ on Dhakandhoo, Hulhudhoo and Thiladhoo respectively. In general, maximum $H$ s values were reduced by half during the northeast monsoon. Results also indicate a cross-atoll reduction in the incident wave heights (windward to leeward) impacting the study islands in both monsoon periods as described in detail by Kench et al. (2006).

At the reef platform scale large differences were not observed in measured wave energy propagating onto the windward and leeward outer reef flat surfaces. In general, maximum $H$ s values differed by only $0.1 \mathrm{~m}$ between the two sides of each reef platform (e.g. Fig. 3). Indeed, in some deployments both the maximum and mean $H s$ values were larger on the leeward reef edge (e.g. Hulhudhoo, Fig. 6b, c). Such observations have not been widely reported in studies of coral reef platforms. These results indicate that geomorphic activity can be expected to be similar on both windward and leeward sides of reef platforms. In instances where the leeward reef receives higher wave 

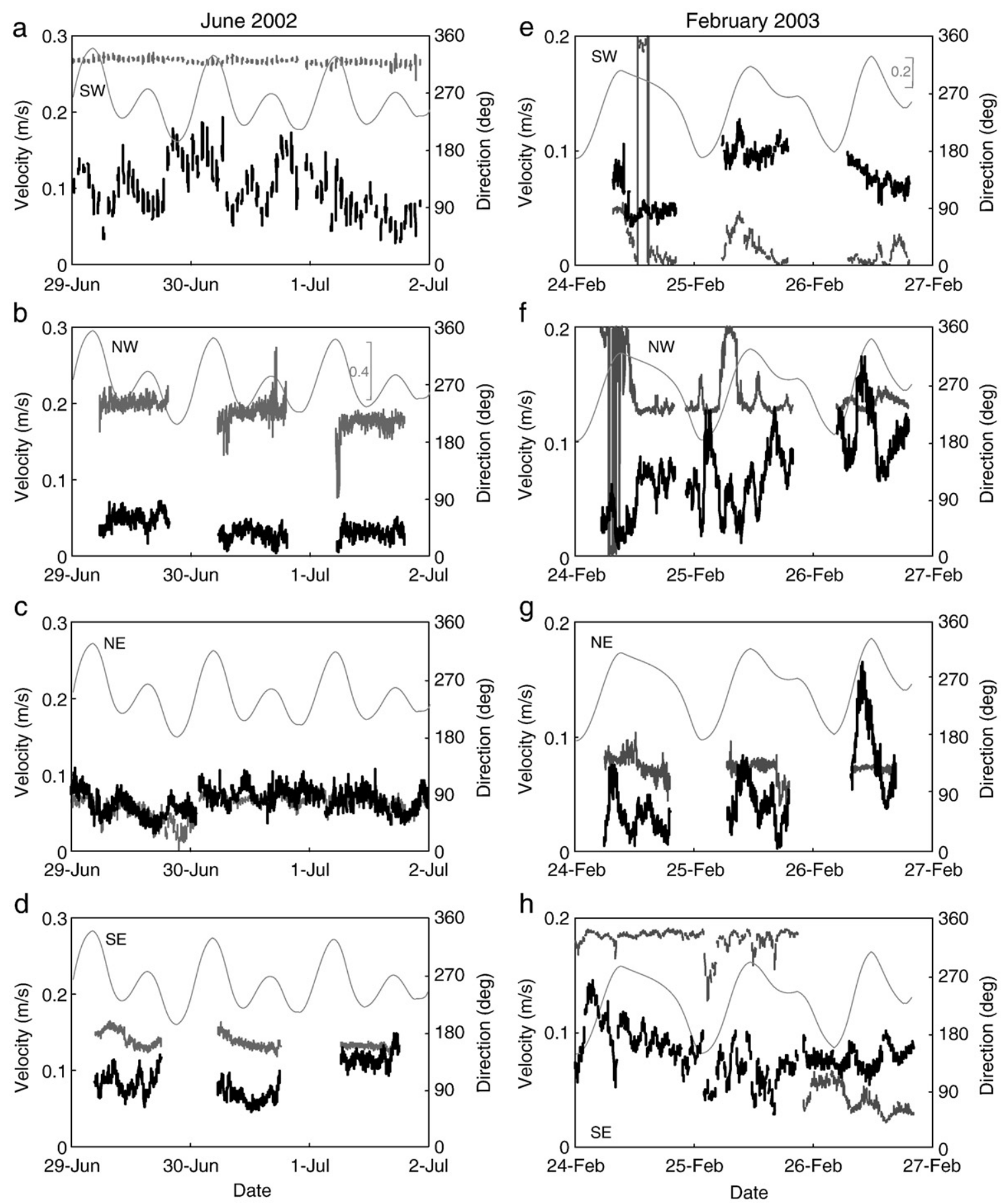

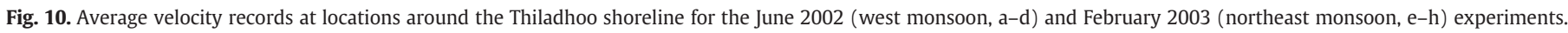

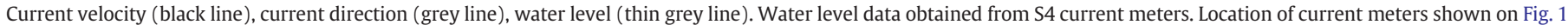

energy the adjacent shorelines are exposed to larger wave energy inputs. A similar observation was made by Kench and Brander (2006b) on Lady Elliot Island, Great Barrier Reef which experienced higher magnitude wave energy on its leeward shoreline.

There are a number of possible explanations for the varied observations of wave height differences between leeward and windward reef flats. First, the small differences in wave heights may reflect the relatively small size of reef platforms allowing refraction processes to take place with minimal loss of wave energy. Second, the reef may filter higher period waves from the wave spectrum on windward reefs. In many experiments comparison of Ts values indicate shorter period waves propagating onto windward reef locations and longer period waves on leeward reef locations (Figs. 3 and 6). These differences in wave period are likely to evolve due to locally generated wind waves (4-7 s) with shorter period and larger height propagating directly onto the reef surface at windward locations as noted by Kench et al (2009). The short length of these waves is likely to limit complete refraction around reefs. In contrast, longer period swell $(>8 \mathrm{~s}$ ) of lower height is more effectively refracted around the reef platforms. Third, wave height differences can be caused by subtle variations in reef elevation (Tables 1 and 2) which constrain wave height (Hardy and Young, 1996; Kench and Brander, 2006a), with higher elevation reefs forcing a greater degree of shoaling as waves interact with the outer reef platform. Fourth, higher leeward wave conditions were observed 


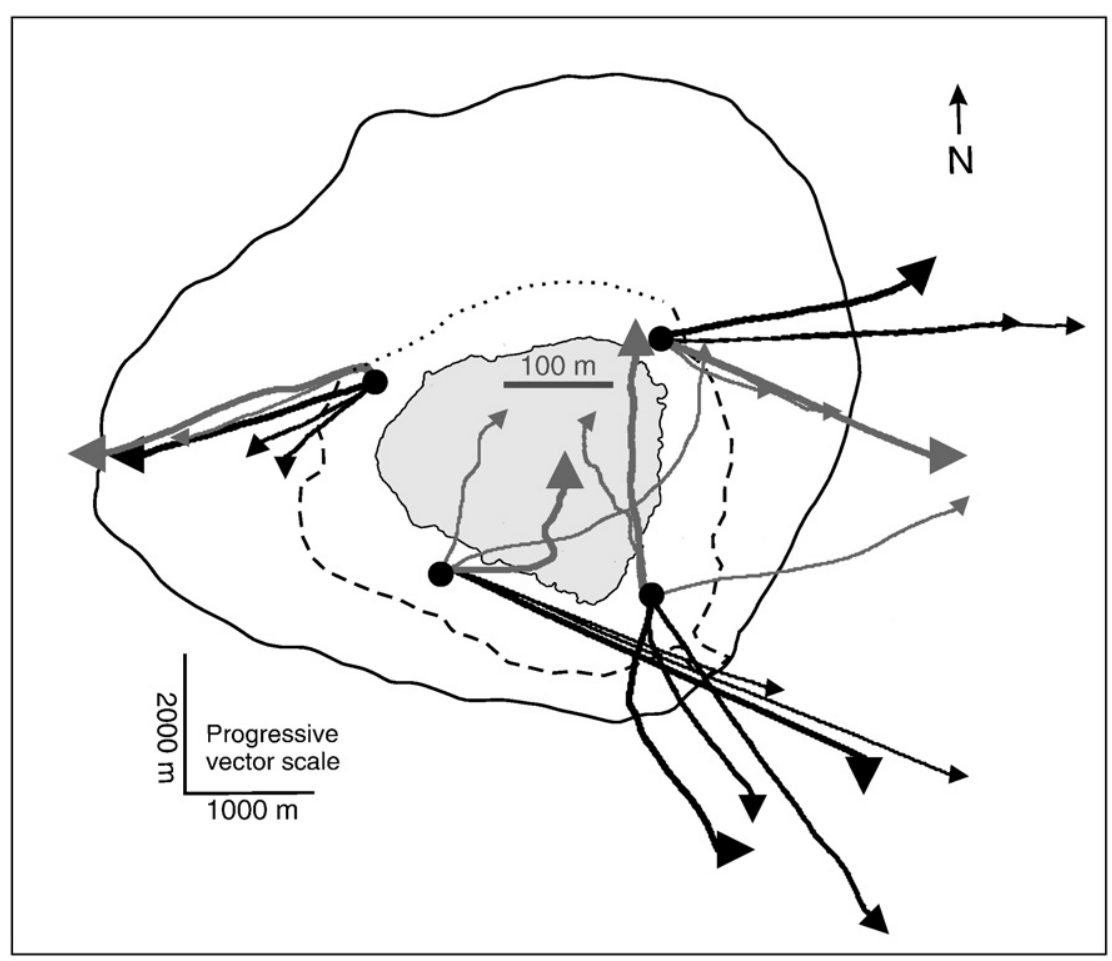

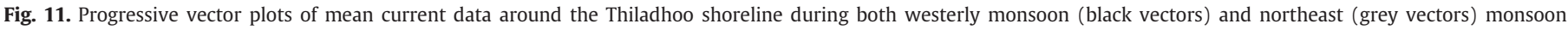

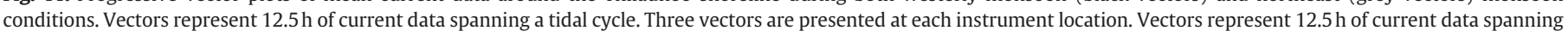
a tidal cycle. Different thickness of vectors represent equivalent 12.5 hour time periods at each nearshore location.

at Hulhudhoo (e.g. Fig. 6b, c). This is the most circular reef platform where complete refraction around the perimeter of reef may result in wave interaction and amplification. Such a process has been reported in studies of tsunami where wave refraction and interaction around the reef platform amplifies leeward wave and runup conditions (Briggs et al., 1995; Liu et al., 1995).

\subsection{Reef flat current generation}

Wave breaking at the outer reef flat has been identified in numerous studies as the principle mechanism generating across reef currents (Symonds et al., 1995; Lugo-Fernández et al., 1998b; Hearn, 1999). Symonds et al. (1995) developed a model that shows that as waves break at the reef crest they generate radiation stress gradients, with set up at the reef edge and a water slope toward a back-reef lagoon, which drives unidirectional currents across a reef surface. Reduced or no setup is expected at higher water levels as waves do not break but propagate onto reef surfaces. Critical in the generation of this setup is the ratio of wave height $(H)$ to water depth at the reef edge $\left(h_{\mathrm{r}}\right)$ (Symonds et al., 1995; Hearn, 1999). Wave driven flow does not occur when $h_{\mathrm{r}}=0$ (i.e. there is no water across the reef edge), increases with $h_{\mathrm{r}}$ to a maximum when $h_{\mathrm{r}}=H / 2$, and declines to 0 at $h_{\mathrm{r}}=H$. As a consequence of this depth-limiting relationship a bimodal velocity signature is expected as shown in instrumental records by Kraines et al. (2001) and Kench and McLean (2004).

On all reef platforms in this study nearshore windward velocity records appear to be modulated by water depth (Figs. 4, 7 and 10). However, the velocity records do not exhibit a marked bimodal velocity signature at mid-tide stages as predicted by Symonds et al. (1995). There are isolated examples where this is apparent (e.g. Fig. $4 \mathrm{~g}$ ), but the dominant pattern is for the velocity maxima to be centred close to low tide stages. This can be explained for windward locations due to the specific wave and water depth conditions on most of the reef platforms. As noted earlier at the study sites the outer reef flats are generally positioned at or below lowest astronomical tide.
Consequently, the reef flats are generally always inundated at low tide (the high southern reef flat at Hulhudhoo being an exception), while at high tides water depth across the outer reef surfaces exceed $1.2 \mathrm{~m}$. Wave heights ranged from $\mathrm{Hs}$ values of 0.45 to $0.2 \mathrm{~m}$ during the westerly monsoon (and considerably less in the northeast monsoon) with depth limitation on waves only being apparent in the strong modulation of $\mathrm{Hs}$ at the windward reef flat site on Dhakandhoo and Thiladhoo (Figs. 3b, f and 9b). This combination of factors (relative deep water and moderate wave heights) can account for the observed velocity signatures (particularly at windward locations). At higher water levels waves were able to propagate onto reef surfaces with little shoaling and breaking, as denoted by the lack of tidal modulation of $\mathrm{Hs}$ values at most wave gauge locations and the fact that higher $\mathrm{Hs}$ values are sustained for periods greater than $12 \mathrm{~h}$ at windward Dhakandhoo locations (Fig. 3b, f). Consequently, wave setupgenerated currents are expected to be small in magnitude at high water levels, as generally observed in most windward nearshore velocity records (e.g. Fig. 4), as waves propagate onto and across reef surfaces. At these higher water stages secondary wave setup may occur across the higher central reef flat, as waves shoal break and bores propagate landwards, or at the island shoreline, as observed by Jago et al. (2007). Under shoreline setup conditions it is anticipated that currents are forced either alongshore or offshore.

\subsection{Current patterns}

Results show that flow patterns on the study platforms were unidirectional (Figs. 5, 8 and 11), which is consistent with the waveinduced mechanism for current generation discussed above. To date, theoretical considerations of wave setup-induced currents have predominantly considered 2-dimensional across-reef flows in which the higher water levels at the reef edge reduce to the still water level in the backreef lagoon (Symonds et al., 1995; Hearn, 1999). On the study platforms such a gradient is either truncated by, or reduced to, the still water surface before reaching the reef island shoreline. Furthermore, 
setup gradients cannot generate solely 2-dimensional across-reef flows where reef island shorelines have a 360 degree perimeter and where waves refract around and propagate shoreward around the entire island perimeter. Results clearly show that while currents are unidirectional, flows are not oriented across the reef but flow parallel with island shorelines (often oblique to the prevailing winds) to convey water from windward to leeward sides of the reef platform (Figs. 5 and 8). These flow pathways are clearly related to the presence and planform configuration of islands as water is conveyed along the shortest hydrodynamic gradient from windward to leeward locations.

While it is convenient to explain such patterns as the interplay between a set-up driven gradient and presence of islands, it must be acknowledged that waves are propagating onto the reefs around their entire perimeter. Consequently, it is possible that two other factors also enhance the observed flow patterns. First, spatial variations in incident wave energy may be expected to promote variations in setup around islands that also control current flow. Variations in wave setup around an island may, in turn, be enhanced by spatial differences in reef elevation (Tables 1 and 2). On the study platforms, reef elevation tends to be highest on the western and southwest sections of Dhakandhoo and Hulhudhoo and north-northeast on Thiladhoo. Incident wave conditions are generally also largest on these exposures of the reef platforms. Consequently, $h_{\mathrm{r}} / H$ ratios suggest that the largest setup can be expected at these westerly windward locations (in the westerly monsoon). Lower elevation reef surfaces on the leeward side of islands (during westerly conditions) imply lower wave setup, which generates an around-island flow pattern. Similar spatial variations in wave setup were invoked by Jago et al. (2007) and acknowledged by Gourlay and Colleter (2005) as providing a mechanism driving alongshore flows around reef islands.

Second, a morphological feedback exists that may play a significant role in enhancing the current flows. The moat is a morphological depression encircling islands that acts as a conduit of flow (between the island shoreline and outer reef surface, Fig. 1f), from windward to leeward locations. Flow through the moat is expected to accelerate at lower tidal stages as water forced onto the reef is effectively trapped within the confines of the deeper moat. Such a response is observed in the velocity records on Hulhudhoo during the westerly monsoon (Fig. $4 \mathrm{a}-\mathrm{c}$ ) as velocity increased toward lower tidal stages on the lateral locations (NW, SE). It is possible that the velocity maxima observed at high tide on the leeward side of Hulhudhoo under the westerly monsoon (Fig. 4c) results from both wave setup at the island shoreline and downwind delivery of flow via the moat system that encircles the island. The role of the moat in conveying water around the island shoreline is also likely to overpower any onshore directed wave setup currents on the leeward side of the island, resulting in the unidirectional offshore flow at these locations (Figs. 5, 8 and 11).

Consequently, moat systems may act as preferential flow mechanisms for water delivered to the reef platforms. This may be enhanced in the westerly monsoon by the fact that the reef flat and moat topography varies, with eastern sides of islands generally having lower elevation than western reef and moat features.

The moats carry substantial volumes of water and at low tide stages it may be expected that velocity conditions increase in the moats due to: i) stronger wave setup across the reef; ii) the moat being effectively hydrodynamically cut-off from the higher elevation surrounding reef flat surface; iii) spatial variations in moat elevation. However, detecting the relative role of wave setup processes and the moat as a morphological current guide is not possible from the data contained herein.

\subsection{Seasonal variations in reef flat current patterns}

Our data from the reef platforms in South Maalhosmadulu atoll show significant changes in the magnitude of wave energy impacting reef platforms and differences in nearshore circulation on each platform between monsoon seasons. Broadscale monsoon-driven changes in the direction and magnitude of wave energy incident at the reef platforms have previously been reported by Kench et al. (2006). Their study also found a general reduction in wave energy across the atoll, a reversal in this energy gradient between seasons and a shift in dominance of swell to wind-generated wave energy from windward to leeward reef platform locations.

Circulation patterns showed distinct changes between monsoon seasons. In general, flows are toward the east under westerly monsoon conditions and toward the south-southwest under northeast monsoon conditions (Figs. 5, 8 and 11). However, no relationship exists between the magnitude of wave energy and current processes. For example, the windward exposed reefs did not exhibit significantly greater currents than centrally located and leeward reefs.

Beneath the broadscale trends, the results reveal distinct differences in circulation patterns between islands and differences in seasonal alteration in current patterns on each island. Such differences are considered to reflect a number of factors: the shape of each platform, which controls localised wave refraction patterns; and, direction and character of waves impacting reefs (swell versus wind waves), which is a function of the boundary wave climate, position of each reef platform within the atoll and their proximity to neighbouring reefs and gaps in the atoll periphery.

Hulhudhoo is located centrally in the lagoon and has small neighbouring reefs immediately to the west and east (Fig. 1). The wave energy incident at Hulhudhoo is typically less than peripheral reefs (Figs. 3, 6 and 9) and is characterised by an absence of oceanic swell and dominance of lagoon generated wind waves that switch in direction seasonally from the west to northeast (Kench et al., 2006). Due to the presence of an adjacent reef to the west maximum wave energy propagates onto the platform from the west to southwest sectors during the west monsoon. Hulhudhoo is also a near circular reef platform and exhibits the most dramatic changes in circulation of all the platforms studied with complete reversal in current flows between the west and northeast monsoon period (Fig. 8). This large change in flow pattern is attributed to the fact that as the direction of incident wave approach alters the circular reef platform is able to reorganise reef flat currents consistent with the new vector of energy input.

The elongate Dhakandhoo platform does not exhibit such significant changes in current patterns between monsoon periods. This is attributed to the bimodal character of waves impacting the reef, which is a consequence of its proximity to a large gap in the western atoll. During westerly monsoon conditions ocean swell and windwave energy propagate from the west driving currents south along the windward shoreline but eastward along the flanks of the island where they drain off the eastern side of the reef platform. In the northeast monsoon the eastern reef receives wind-generated wave energy which is generated inside the atoll lagoon (Fig. 3e, Kench et al., 2006). Under these conditions currents are directed toward the south at the eastern tip of the island and currents flow to the northnorthwest on the northern shoreline (Fig. 5). However, the summary wave data (Fig. 3f) and wave energy spectra (see Kench et al., 2006) from the western reef platform show waves there are dominated by long period swell which accesses the lagoon through the gap in the western atoll rim. Refraction around a large reef to the northwest ensures that swell conditions are similar to the westerly monsoon and, while lower in magnitude (Fig. 2c), are able to maintain southerly flow at the western (leeward) tip of the island and easterly flow along the southern shoreline (Fig. 5). As a consequence only the northern shoreline and eastern end of the island experiences significant variation in current patterns between monsoons.

Thiladhoo displayed the least variation in current patterns between monsoon seasons and is most complex to explain. Current patterns on the north and western shorelines remain in divergent easterly and southwesterly directions respectively between monsoons (Fig. 11). Most noticeable changes occur on the southern and particularly the 
southeast shorelines where current flow changes to the northnortheast, representing a near 180 degree shift in current direction from the westerly monsoon season (Fig. 11). While positioned on the eastern side of the atoll neighbouring reef platforms to the east and northeast provide wave shelter to Thiladhoo. Consequently, the largest fetch distances are to the northwest (gap in atoll rim) and westsouthwest, which are likely to control wave approach to Thiladhoo with persistent higher energy across the northwestern reef surface. The change in flow toward the north, on the southeast side of the island, is difficult to explain but may be controlled by easterly swell leaking through the atoll periphery, refraction and a southerly approach to the reef platform.

\subsection{Circulation control on morphodynamics of island shorelines}

Monsoonally-forced changes in nearshore wave and current patterns control seasonal morphological responses of island beaches. Fig. 12 shows summary GPS surveys documenting the position of beaches on each island between monsoon seasons. The data show large changes in beach position between monsoon periods, which Kench and Brander (2006a) link to differences in reef platform shape. Waves and currents provide the process mechanism that drives change in shoreline position between seasons. Analysis of high frequency current records indicate that velocities in the nearshore commonly exceed the threshold condition for medium-sized carbonate sediments $\left(\sim 0.20 \mathrm{~ms}^{-1}\right.$, Kench and McLean, 1996). Furthermore, sediment was observed to be highly mobile in the swash zone of all beaches. Once entrained, unidirectional shoreline currents would transfer sediment alongshore to leeward depocentres and govern the reorganisation of mobile beach materials around the study islands (Fig. 12). Of note, beaches show the greatest degree of morphological change at locations where current patterns exhibit the largest changes between monsoon seasons.

Differences in current patterns between reef platforms also account for variations in planform beach dynamics between islands. For example, on Dhakandhoo, it is the eastern tip of the island that exhibits greatest morphological variability. Under westerly monsoon conditions eastward draining flow allows extension of the terminal spit by up $60 \mathrm{~m}$ across the reef flat (Fig. 12a). However, under northeast conditions only currents on the east and northern shoreline show significant alteration in flow direction (Fig. 5). Such changes remobilise sediment from the eastern tip and transport them along the northern and southern shoreline resulting in truncation of the eastern tip (by up to $60 \mathrm{~m}$ ) and minor expansion of the sandy shoreline toward the eastern end of the northern and southern shoreline.

On Hulhudhoo the current patterns reverse between monsoons. Consequently, the mobile beach shifts between the northeast, where a depositional lobe up to $35 \mathrm{~m}$ wide is deposited at the end of the westerly monsoon, and the northeast monsoon where a depositional lobe occurs on the western side of the island (Fig. 12c, d). Reorganisation of this sediment amounts to approximately $46 \times 10^{3} \mathrm{~m}^{3}$ per year and flow patterns highlight that this is predominantly an alongshore transfer of sediment (Kench and Brander, 2006a). Furthermore, the northern and southern shorelines do not exhibit significant fluctuations in shoreline position, implying that these are primarily sediment bypass zones as currents (highest on the lateral flanks) transfer sediment to leeward depocentres (Fig. 12c).

On Thiladhoo, beach morphological change is greatest at the southeastern apex of the island, which corresponds to the area of greatest change in current patterns between seasons. In particular, the central position of the lobe of sand on the southeastern node oscillates laterally by up to $60 \mathrm{~m}$ between seasons (Fig. 12e, f).

\subsection{Broader geomorphic implications}

This study presents the first detailed process linkages between waves, currents and consequent shoreline dynamics on three reef platform islands in the Maldives. The findings provide insights into the morphodynamic behaviour of reef islands that are likely to have implications in other reef platform settings.

Our findings show that reef island shorelines are dominated by alongshore current and sediment transport processes as opposed to the cross-shore exchange of sediment that typically characterises linear or siliciclastic shorelines. Alongshore process and morphological change signatures are likely to dominate on other reef platforms where wave refraction around the reef structure can take place, but is not likely to occur on islands situated on extensive linear atoll reef rims where wave refraction is precluded by the reef extent and/or presence of a backing lagoon.

Results indicate that the magnitude of shoreline change may vary as a consequence of reef platform shape, as they modulate incident wave processes. Based on analysis of seasonal shoreline change on 8 islands in South Maalhosmadulu atoll Kench and Brander (2006a) proposed the island oscillation index (Io) which showed that the magnitude of island shoreline change was positively correlated with circularity of reef platforms. Our process data supports this with the circular island (Hulhudhoo) exhibiting the greatest degree of change in both nearshore circulation and shoreline adjustment between monsoons. In contrast the elongate island (Dhakandhoo) exhibits the least amount of change in both circulation patterns and shoreline adjustment. Consequently, reef platform shape may provide a reliable first order predictor of the relative susceptibility of islands to shoreline change in response to changing wave regimes.

The study results also indicate that reef platform current patterns and island morphodynamics are not sensitive to the magnitude and changes in magnitude of wave energy incident at reef platforms. For example, the circular island (Hulhudhoo) had the most dynamic shoreline despite it receiving lower magnitude wave energy inputs than other sites. In contrast, the elongate reef platform island (Dhakandhoo) exhibits the least amount of shoreline change despite its highest energy exposure on the western atoll rim. These morphodynamic observations have some parallels to the behaviour of microtidal beaches in which highest and lowest energy beaches are morphologically more stable than intermediate beach types (Wright and Short, 1984). However, our results suggest that rather than change in gross energy, it is the magnitude of change in direction of wave approach that is the most important control on island morphodynamics. This is best illustrated on the circular reef platform at Hulhudhoo. In the absence of oceanic swell monsoonal winds control shifts in the incident direction of wind-wave energy (from west to northeast) and results in reversing circulation around the island and large excursions of shoreline position. While similar changes in wind-wave direction occur at Dhakandhoo, southwesterly oceanic swell is still able to influence the process regime on this peripheral reef throughout the year. Consequently, the platform does not experience complete change in directional wave energy input and both changes in current patterns and shoreline behaviour are more subdued. Further investigations of process controls on shoreline change on islands of varied shape and differing wave climates are required to test these concepts and develop a more robust morphodynamic framework of reef platform islands.

Recognition that shoreline change is dominated by alongshore movement of materials and that islands have varied susceptibility to shoreline change due to a combination of reef platform shape and degree of change in wave approach has significant implications for management of these dynamic shorelines. Globally, the physical management of reef island shorelines has relied on standard coastal engineering techniques (seawalls, groynes) that compromise the natural functioning of island shorelines and invariably exacerbate and or promote shoreline instability (Maragos, 1993; Kench et al., 2003). Analysis of the alongshore sweepzone of shoreline change on reef islands can underpin future management decisions and focus necessary coastal infrastructure on more stable sectors of island 


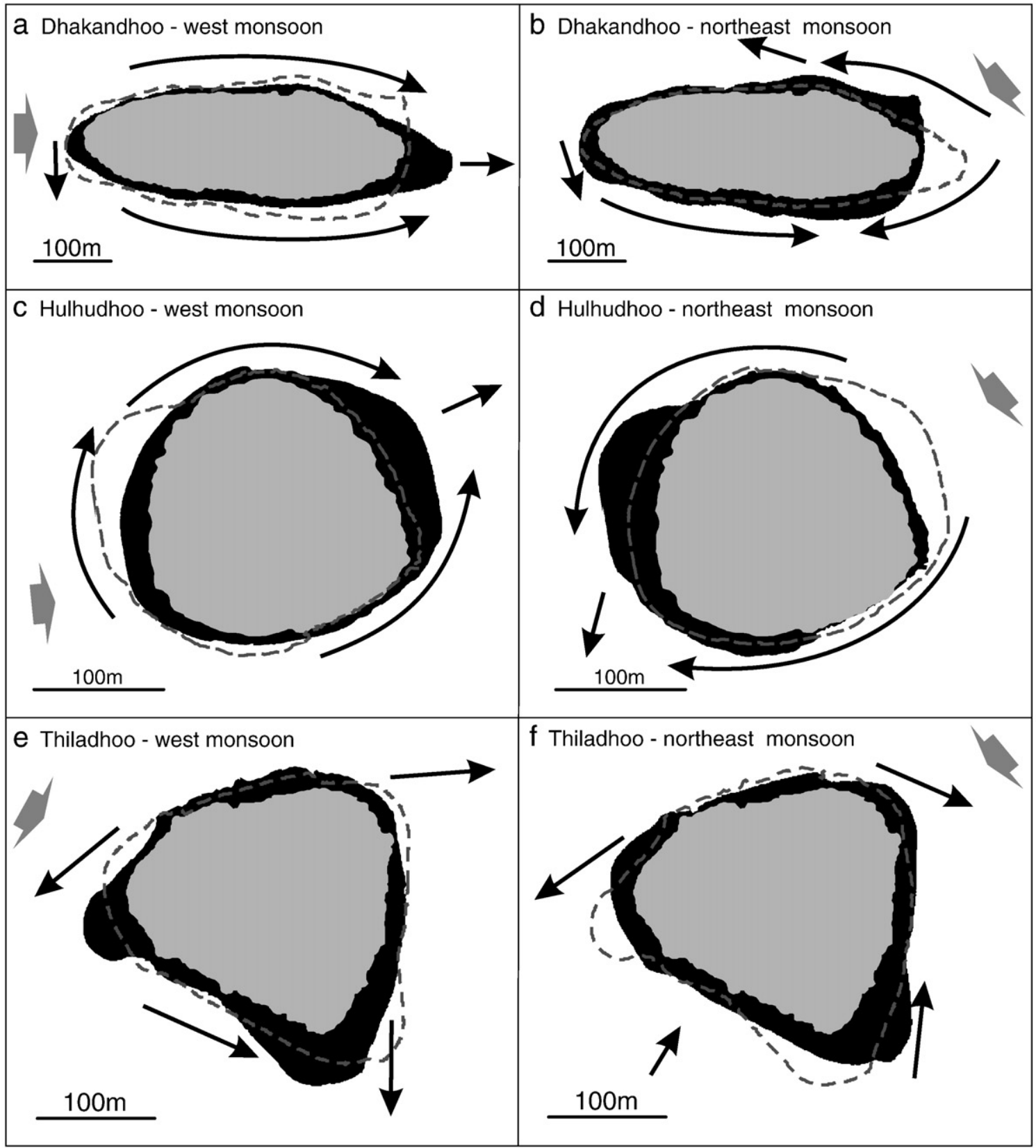

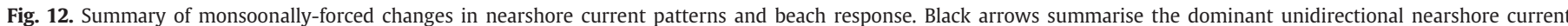

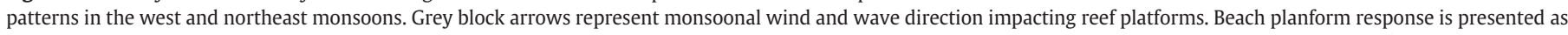

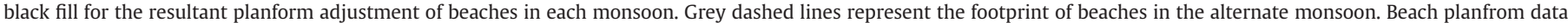
generated from GPS surveys during the hydrodynamic experiments. GPS data presented in full in Kench and Brander (2006a).

shorelines, therefore, avoiding interference with nearshore current processes and sediment fluxes.

\section{Conclusions}

Hydrodynamic experiments involving synchronous measurements of incident wave characteristics on the outer reef and currents in the nearshore surrounding three reef platform islands in the Maldives show that wind and wave-driven flow drives reef platform circulation. Islands act as morphological feedbacks controlling flow patterns from windward to leeward sides of the reef around island shorelines. While wind and wave energy govern incident energy inputs and control the generation of currents on reef surfaces, mechanisms controlling circulation are likely to include spatial variations in wave setup around island shorelines and topographic variations in reef elevation.
On the study islands 'reef moats' act as morphological conduits of flow from windward to leeward sides of islands.

Experiments show that the switching monsoons modulate the direction and magnitude of wave energy propagating onto reef surfaces. Consequently, nearshore current processes were also shown to change significantly between monsoons, although the degree of changes was influenced by reef and island shape and the nature of wave processes propagating onto reefs. The most dramatic reversal in current flow occurred on the circular reef platform, Hulhudhoo.

Monsoonally-forced changes in nearshore current patterns alter alongshore gradients in sediment flux, which results in substantial changes in beach configuration between seasons around the perimeter of island shorelines. Of note, beaches are most mobile on those sections of coast that exhibit the largest degree of alteration in current flow direction. In this study the circular island exhibited the greatest 
change in current patterns and morphological change whereas the elongate reef island displayed least change in current patterns and shoreline variability.

Results have significant implications for reef platform island morphodynamics. First, short-term shoreline change is dominated by alongshore processes as opposed to cross-shore exchanges. Second, results provide predictive clues as to the most sensitive and least sensitive geometries of reef island shorelines to changes in the process regime. For example, large plannimetric changes in shoreline position are expected where current patterns are most influenced by seasonal adjustments in currents. Third, reef platform shape and the degree of change in wave approach to reef platforms are identified as critical indicators of the morphodynamic behaviour of reef platform islands. Further testing of these indicators is required to develop a robust morphodynamic framework for reef islands.

\section{References}

Abelson, A., Denny, M., 1997. Settlement of marine organisms in flow. Ann. Rev. Ecol. Syst. 28, 317-339.

Aston, J.P., 1995. The relative mobilities of coral cays on the GBR can be modelled, M.S. thesis, 267 pp., James Cook Univ., Townsville.

Bayliss-Smith, T.P., 1988. The role of hurricanes in the development of reef islands, Ontong Java atoll, Solomon Islands. Geogr. J. 154, 377-391.

Black, K.P., 1993. The relative importance of local retention and inter-reef dispersal of neutrally buoyant material on coral reefs. Coral Reefs 12, 43-53.

Brander, R.W., Kench, P.S., Hart, D.E., 2004. Spatial and temporal variations in wave characteristics across a reef platform, Warraber Island, Torres Strait, Australia. Mar. Geol. 207, 169-184.

Briggs, M.J., Synolakis, C.E., Harkins, G.S., Green, D.R., 1995. Laboratory experiments of tsunami runup on a circular island. Pure Appl. Geophys. 144, 569-593.

Department of Meteorology, 1995. Some Meteorological data 1966-1994. Report of the Meteorological Department, Government of Maldives.

Flood, P.G., 1984. In: Ward, W.T., Saenger, P. (Eds.), Variability in shoreline position on five uninhabited islands of the Capricorn Section, GBR Marine Park in The Capricornia Section of the GBR: Past, Present and Future. Royal Society of Queensland and Australian Coral Reef Society, Brisbane, pp. 17-24.

Flood, P.G., 1986. Sensitivity of coral cays to climatic variations, southern Great Barrier Reef, Australia. Coral Reefs 5, 13-18.

Flood, P.G, Jell, J.S., 1977. The effects of cyclone 'David' on the sediment distribution patterns on Heron Reef, Great Barrier Reef, Australia. Proc. 3rd Int. Coral Reef Symp., pp. 119-125.

Frith, C.A., 1982. Circulation in a platform reef lagoon, One Tree Reef, southern Great Barrier Reef. Proc. 4th Int. Coral Reef Symp., vol. 1, pp. 347-354.

Frith, C.A., Mason, L.B., 1986. Modelling wind-driven circulation, One Tree Reef, southern Great Barrier Reef. Coral Reefs 4, 201-211.

Gerritsen, F., 1981. Wave attenuation and wave set-up on a coastal reef. Proc. 17th Int. Conf. Coast. Eng. ASCE, pp. 444-461.

Gourlay, M.R., 1988. 'Coral Cays' products of wave action and geological processes in a biogenic environment. Proc. 6th Int. Coral Reef Symp. Australia, pp. 491-496.

Gourlay, M.R., 1994. Wave transformation on a coral reef. Coast. Eng. 23, 17-42.

Gourlay, M.R., 1996a. Wave set-up on coral reefs. 1. Set-up and wave generated flow on an idealised two dimensional horizontal reef. Coast. Eng. 27, 161-1935.

Gourlay, M.R., 1996b. Wave set-up on coral reefs. 2. Set-up on reefs with various profiles. Coast. Eng. 28, 17-55.

Gourlay, M.R., Colleter, G., 2005. Wave-generated flow on coral reefs - An analysis for two-dimensional horizontal reef-tops with steep faces. Coast. Eng. 52, 353-387.

Hamner, W.H., Wolanski, E., 1988. Hydrodynamic forcing functions and biological processes on coral reefs: a status review. Proc. 6th Int. Coral Reef Symp., vol. 1, pp. 8-12.

Harangozo, S.A., 1992. Flooding in the Maldives and its implications for the global sea level rise debate. Sea Level Changes: Determination and Effects, Geophysical Monograph 69, IUGG, 11, 95-100.

Hardy, T.A., Young, I.R., 1996. Field study of wave attenuation on an offshore coral reef. J. Geophys. Res. C101, 14311-14326.

Hardy, T.A., Young, I.R., Nelson, R.C., Gourlay, M.R., 1990. Wave attenuation on an offshore coral reef. Proc. 22nd Int. Coast. Eng. Conf. 1, 330-344.

Harmelin-Vivien, M.L., 1994. The effects of storms and cyclones on coral reefs: a review. J. Coast Res. Spec. Iss. 12, 211-231.

Hearn, C.J., 1999. Wave-breaking hydrodynamics within coral reef systems and the effect of changing relative sea level. J. Geophys. Res. 104 (C12), 30007-30019.

Hearn, C.J., Atkinson, M.J., Falter, J.L., 2001. A physical derivation of nutrient-uptake rates in coral reefs: effects of roughness and waves. Coral Reefs 20,347-356.

Jago, O.K., Kench, P.S., Brander, R.W., 2007. Field observations of wave-driven waterlevel gradients across a coral reef flat. J. Geophys. Res. 112, C06027. doi:10.1029/ 2006JC003740.

Jokiel, P.L., 1978. Effects of water motion on reef corals. J. Exp. Mar. Biol. Ecol. 35, 87-97.

Kench, P.S., 1998a. Physical controls on development of lagoon sand deposits and lagoon infilling in an Indian Ocean atoll. J. Coast. Res. 14, 1014-1024.

Kench, P.S., 1998b. Physical processes in a semi-enclosed Indian Ocean atoll. Coral Reefs $17,155-168$.
Kench, P.S., Brander, R.W., 2006a. Response of reef island shorelines to seasonal climate oscillations: South Maalhosmadulu atoll, Maldives. J. Geophys. Res. 111, F01001. doi:10.1029/2005JF000323.

Kench, P.S., Brander, R.W., 2006b. Wave processes on coral reef flats: implications for reef geomorphology using Australian case studies. J. Coast. Res. 22, 209-223.

Kench, P.S., McLean, R.F., 1996. Hydraulic characteristics of bioclastic deposits: new possibilities for environmental interpretation using settling velocity fractions. Sedimentology 43, 561-570.

Kench, P.S., McLean, R.F., 2004. Hydrodynamics and sediment flux of hoa in an Indian Ocean atoll. Earth Surf. Proc. Landf. 29, 933-953.

Kench, P.S., Parnell, K.E., Brander, R.W., 2003. A process based assessment of engineered structures on reef islands of the Maldives. In: Kench, P.S., Hume, T.M. (Eds.), Proc. Coasts and Ports Aust. Conf., vol. 75. 10 pp.

Kench, P.S., Brander, R.W., Parnell, K.E., McLean, R.F., 2006. Wave energy gradients across a Maldivian atoll: Implications for island geomorphology. Geomorphology $81,1-17$.

Kench, P.S., Brander, R.W., Parnell, K.E., O'Callaghan, J.M., 2009. Seasonal variations in wave characteristics around a coral reef island, South Maalhosmadulu atoll, Maldives. Mar. Geol. 262, 116-129.

Kraines, S.B., Yanagi, T., Isobe, M., Komiyama, H., 1998. Wind-wave driven circulation on the coral reef at Bora Bay, Miyako Island. Coral Reefs 17, 133-143.

Kraines, S.B., Isobe, M., Komiyama, H., 2001. Seasonal variations in the exchange of water and water-borne particles at Majuro Atoll, the Republic of the Marshall Islands. Coral Reefs 20, 330-340.

Lee, T.T., Black, K.P., 1978. The energy spectra of surf waves on a coral reef. Proc. 16th Int. Conf. Coast. Eng. ASCE, pp. 588-608.

Liu, P.L.-F., Cho, Y.-S., Briggs, M.J., Kanoglu, U., Synolakis, C.E., 1995. Runup of solitary waves on a circular island. J. Fluid Mech. 302, 259-285.

Lugo-Fernández, A., Roberts, H.H., Wiseman Jr., W.J., 1998a. Tide effects on wave attenuation and wave set-up on a Caribbean Coral Reef. Est. Coast. Shelf Sci. 47, 385-393.

Lugo-Fernández, A., Roberts, H.H., Wiseman, W.J., Carter, B.L., 1998b. Water level and currents of tidal and infragravity periods at Tague Reef, St Croix (USVI). Coral Reefs 17, 343-349.

Lugo-Fernández, A., Roberts, H.H., Wiseman, W.J., 2004. Currents, water levels, and mass transport over a modern Caribbean coral reef: Tague Reef, St. Croix, USVI. Cont. Shelf Res. 24, 1989-2009.

Macintyre, I.G., Graus, R.R., Reinthal, P.N., Litter, M.M., Litter, D.S., 1987. The Barrier Reef sediment apron: Tobacco Reef, Belize. Coral Reefs 6, 1-12.

Maragos, J.E., 1993. Impact of coastal construction on coral reefs in the U.S.-affiliated Pacific Islands. Coast. Man. 21, 235-269.

Maragos, J.E., Baines, G.B.K., Beveridge, P.J., 1973. Tropical Cyclone Bebe creates a new land formation on Funafuti atoll. Science 181, 1161-1181.

Nakamori, T., Suzuki, A., Iryu, Y., 1992. Water circulation and carbon flux on Shiraho coral reef of the Rykuyu Island, Japan. Cont. Shelf Res. 12, 951-970.

Pickard, G.L., 1986. Effects of wind and tide on upper-layer currents at Davies Reef, Great Barrier Reef, during MECOR (July-August 1984). Aust. J. Mar. Freshwater Res. 37, 545-565.

Prager, E.J., 1991. Numerical simulation of circulation in a Caribbean-type backreef lagoon. Coral Reefs 10, 177-182.

Purdy, E.G., Gischler, E., 2005. The transient nature of the empty bucket model of reef sedimentation. Sed. Geol. 175, 35-47.

Roberts, H.H., 1975. Physical processes in a fringing reef system. J. Mar. Res. 33, 233-260.

Roberts, H.H., Suhayda, J.N., 1983. Wave current interactions on a shallow reef (Nicaragua). Coral Reefs 1, 209-260.

Roberts, H.H., Wilson, P.A., Lugo-Fernandez, A., 1992. Biologic and geologic responses to physical processes: examples from modern reef systems of the Caribbean-Atlantic region. Cont. Shelf Res. 12 (7/8), 809-834.

Samosorn, B., Woodroffe, C.D., 2008. Nearshore wave environments around a sandy cay on a platform reef, Torres Strait, Australia. Cont. Shelf Res 28, 2257-2274.

Stoddart, D.R., 1963. Effects of Hurricane Hattie on the British Honduras reefs and cays, October 30-31, 1961. Atoll Res. Bull. 95, 1-142.

Stoddart, D.R., 1971. Coral reefs and islands and catastrophic storms. In: Steers, J.A. (Ed.), Applied Coastal Geomorphology. Macmillan and Co. Ltd., London, pp. 155-197.

Stoddart, D.R., Steers, J.A., 1977. The nature and origin of coral reef islands. In: Jones, O.A., Endean, R. (Eds.), Biology and Geology of Coral Reefs, vol. 4. Academic Press, New York, pp. 59-105.

Stoddart, D.R., McLean, R.F., Scoffin, T.P., Gibbs, P.E., 1978. Forty five years of change on low wooded islands, Great Barrier Reef. Phil. Trans. Roy. Soc. Lond. 284, 63-80.

Stoddart, D.R., Fosberg, F.R., Sachet, M.-H., 1982. Ten years of change on the Glover's Reef cays. Atoll Res. Bull. 257, 1-17.

Storlazzi, C.D., Ogston, A.S., Bothner, M.H., Field, M.E., Presto, M.K., 2004. Wave-and tidallyinduced flow and sediment flux across a fringing coral reef: Southern Molokai, Hawaii. Cont. Shelf Res. 24, 1397-1419.

Storlazzi, C.D., McManus, M.A., Logan, J.B., McLaughlin, B.E., 2006. Cross-shore velocity shear, eddies and heterogeneity in water column properties over fringing coral reefs: West Maui, Hawaii. Cont. Shelf Res. 26, 401-421.

Symonds, G., Black, K.P., Young, I.R., 1995. Wave-driven flow over shallow reefs. J. Geophys. Res. 100 (C2), 2639-2648.

Tait, R.J., 1972. Wave setup on coral reefs. J. Geophys. Res. 77, 2207-2211.

Taylor, J., 1924. Movement of sand cays. Queensl. Geograph. J. 39, 38-39.

Umbgrove, J.H.F., 1947. Coral reefs of the East Indies. Geol. Soc. Am. Bull. 58, 729-777.

Verstappen, H.Th., 1954. The influence of climatic change on the formation of coral islands. Am. J. Sci. 252, 428-435.

Woodroffe, C.D., McLean, R.F., Smithers, S.G., Lawson, E.M., 1999. Atoll reef-island formation and response to sea-level change: West Island, Cocos (Keeling) Islands. Mar. Geol. 160, 85-104. 
Wolanski, E., King, B., 1990. Flushing of Bowden Reef lagoon, Great Barrier Reef. Coast. Shelf Sci. 31, 789-804.

Wright, L.D., Short, A.D., 1984. Morphodynamic variability of surf zones and beaches: a synthesis. Mar. Geol. 56, 93-118.

Yamano, H., Kayanne, H., Yonekura, N., Nakamura, H., 1998. Water circulation in a fringing reef located in a monsoon area: Kabira Reef, Ishigaki Island, southwest Japan. Coral Reefs 17, 89-99.
Yamano, H., Miyajima, T., Koike, I., 2000. Importance of foraminifera for the formation and maintenance of a coral sand cay: Green Island, Australia. Coral Reefs 19, 51-58. Young, I.R., 1999. Seasonal variability of the global ocean wind and wave climate. Int. J. Clim. 19, 931-950. 